\title{
Household Financial Assets in the Process of Development
}

\author{
Patrick Honohan*
}

August 2006

\begin{abstract}
Systematic information on household financial asset holdings in developing countries is very sparse; we review some available data and current policy debates. Although financial asset holdings by households are highly concentrated, deeper financial systems are correlated with improved income distribution. For low-income countries, the relevant question for poor households is not how much financial assets they have, but whether they have any access to financial products at all. Building on and synthesizing disparate data collection efforts by others, we produce new estimates of access percentages for over 150 countries. Across countries, access is negatively correlated with poverty rates, but the correlation is not a robust one, thus the supposed anti-poverty potential of financial access remains econometrically elusive. Despite policy focus on the value of credit instruments, it is deposit products that tend to be the first to be used as prosperity increases, before more sophisticated savings products and borrowing.
\end{abstract}

Keywords: household behaviour, asset holding, credit, income distribution, poverty JEL classification: D1, D12, D31

Copyright (C) UNU-WIDER 2006

*The World Bank and CEPR

This study has been prepared within the UNU-WIDER project on Personal Assets from a Global Perspective, directed by Jim Davies.

UNU-WIDER acknowledges with thanks the financial contributions to its research programme by the governments of Denmark (Royal Ministry of Foreign Affairs), Finland (Ministry for Foreign Affairs), Norway (Royal Ministry of Foreign Affairs), Sweden (Swedish International Development Cooperation Agency_Sida) and the United Kingdom (Department for International Development). 


\section{Acknowledgements}

I am grateful to the project organizer Jim Davies and to participants at the project meeting in Helsinki, 4-6 May 2006, as well as to Priya Basu, Francesco Gaetano, Tae Soo Kang, Jaechil Kim, Li Shi, Steve Peachey, Ding Sai, Daniel Waldenström and Jae Hoon Yoo for suggestions and advice on data sources and to Ying Lin for excellent research assistance.

The World Institute for Development Economics Research (WIDER) was established by the United Nations University (UNU) as its first research and training centre and started work in Helsinki, Finland in 1985. The Institute undertakes applied research and policy analysis on structural changes affecting the developing and transitional economies, provides a forum for the advocacy of policies leading to robust, equitable and environmentally sustainable growth, and promotes capacity strengthening and training in the field of economic and social policy making. Work is carried out by staff researchers and visiting scholars in Helsinki and through networks of collaborating scholars and institutions around the world. www.wider.unu.edu publications@wider.unu.edu

UNU World Institute for Development Economics Research (UNU-WIDER)

Katajanokanlaituri 6 B, 00160 Helsinki, Finland

Camera-ready typescript prepared by Lorraine Telfer-Taivainen at UNU-WIDER

The views expressed in this publication are those of the author(s). Publication does not imply endorsement by the Institute or the United Nations University, nor by the programme/project sponsors, of any of the views expressed. 


\section{Introduction}

The financial sector plays a multidimensional role in the process of development. It mobilizes and concentrates resources for investment and allocates them based on an assessment of risk and return, judging creditworthiness and monitoring performance. It offers risk-reduction and risk-pooling services that have both direct effects on welfare (by providing insulation from shocks) and indirect effects on growth, by making riskier-but potentially high-yield —investments in human and physical capital accessible. While much of the recent literature focuses on the interaction of enterprises, large and small, with financial markets and financial intermediaries, households are important consumers of financial products and household behaviour influences the scale and asset mix of finance. Furthermore, poverty and welfare can be strongly influenced by the degree to which households have access to the formal financial sector.

This paper reviews these three dimensions (mobilization, access and risk-reduction) in a quantitative context, concentrating on illustrating some of the very limited data that are available for developing countries. Because the discussion combines data, econometric and conceptual issues, we begin with an extended introduction and summary allowing the main threads of the story to be presented without technical digression.

\section{Mobilization and concentration}

The first dimension relates to the role of household financial asset accumulation in helping mobilize resources that can be effectively deployed for productive investment, thereby accelerating growth. There is clearly something to this mechanism, inasmuch as the well-documented link between banking depth and subsequent economic growth almost necessarily entails household accumulation of bank deposits to back the intermediation that is involved here. However, it needs to be recognized that financial asset holdings are highly concentrated, even more so than non-financial assets, to the extent that the financial assets of the lower quartiles can be largely ignored in any discussion of national resource mobilization. This is true for the United States and other advanced economies, and likely holds with even more force for developing countries.

Wealthy households in many developing countries prefer to hold a relatively large fraction of their assets in safer, more transparent, more diversified and more efficient financial markets offshore. 1 Since such holdings may be illegal because of remaining exchange controls, or because taxes were not paid, offshore holdings would not show up in survey data, and this is likely one of the reasons that most developing countries have

1 Identified offshore banking deposits as a share of GDP are statistically uncorrelated across countries with per capita GDP (Hanson 2003). Hence, since the elasticity of total bank deposits with respect to income is well over one, we may conclude that poorer countries tend to hold a higher share of their financial assets offshore. 
not conducted comprehensive surveys of financial asset holdings of households. The share of financial assets in the average household's domestic portfolio increases with the national level of development (and in advanced economies it increases also with the wealth of the household). Within financial assets, holdings of risky assets are even more concentrated: for these, holdings below the top five per cent of wealthholders are nationally negligible. Curiously, even though the financial assets of the poor are in aggregate negligible, it appears that countries with deeper financial systems have less absolute poverty, even after taking account of mean national income. This suggests that a deep financial system also affects the structure of the economy in subtle ways that are relevant for the inclusiveness of economic development.

\section{Access}

The main focus of current policy concern with regard to household finance in developing countries is the perceived need to increase the access of poor households to basic financial services; deposits, payments, insurance and credit. In other words, policy-driven research for such countries has focused not on allocation decisions between different assets, or on total amounts held, but simply on whether a participation threshold has been reached.

Whether examined from household survey data, or from inference based on numbers of bank and other financial intermediary accounts, it is clear that the fraction of households using 2 the services of formal 3 financial intermediaries is small in most developing countries. In contrast, access percentages in the 1980s and 1990s are recorded for households in advanced economies (where the relevant policy issues are best discussed in the language of exclusion rather than of access). Despite the lack of concrete evidence, it is also generally believed that there is also a direct role for the financial system in reducing poverty by reaching more households with microfinance services. But the scale of this impact remains unclear. Access percentages are correlated with poverty rates and national per capita income, but not very closely. However, conditioning on mean national income, attempts (including in this paper) to detect a statistically robust causal relationship on cross-country data between financial access and poverty have not been successful to date. Intriguingly, then, the strongest crosscountry econometric evidence for a financial sector impact on poverty relates to financial depth (total value of private credit in relation to GDP), and not financial access (percentage of households with an account). Whether this is a causal effect is unclear.

\footnotetext{
2 There is an obvious and important conceptual distinction between access and usage, and surveys often explore this (for further discussion, see Honohan 2004b). In the present paper we treat the terms synonymously, which may not be too bad an approximation when equating access to the use of any financial product.

3 The discussion is generally confined to the formal financial system and as such excludes borrowing from informal lenders and participation in, for example, informal rotating savings and credit schemes.
} 
Microeconomic studies on the impact of microfinance on poverty are also surprisingly inconclusive. Although beneficiaries of microfinance schemes are vocal in their praise and gratitude, a comprehensive assessment needs to consider displacement effects and endogeneity of financial access. Only in a few cases so far has it been possible to devise convincing ways of adjusting for, or excluding, these complicating factors. On balance, most observers regard microfinance interventions as poverty-reducing, while continuing to call for further analysis of methodologies for increasing cost-effectiveness and sustainability of these initiatives, most of which continue to benefit from external subsidies.

\section{Risk reduction and the asset mix}

Turning to the allocation of household assets among financial assets with different risk profiles, the focus shifts to risk-reduction for these households. After all, given the ability of intermediaries to pool risk, household behaviour is only of limited importance in influencing the national supply of risk-finance. Much of the recent literature on household financial asset allocation has been driven by a concern that households are not allocating their savings in an optimal manner. The suggestion is often made that, whether because of erroneous risk calculations, or simply out of ignorance, households fail to adopt strategies and products that would give them a dominant risk-return mix. To the extent that household investment allocation errors are confined to lower-wealth households, they are unlikely to significantly affect macroeconomic aggregates.

For developing countries, the bulk of the population has no practical access to sophisticated financial instruments (or even to such products as medium-term residential mortgages). As economies become more prosperous, increasing proportions of the population begin to move beyond deposit products into life insurance, loans and other more sophisticated products. To that extent, despite considerable interest in the topic, the relevance of such concerns for poverty reduction and growth remain for the present limited.

\section{Implications}

In considering policy with respect to household finance in developing countries, it is not unreasonable to distinguish rather sharply between the objectives of 'finance for growth' and 'finance for all'. Sustained national economic growth calls for the intermediation of sizable resources through an efficient financial system. To the extent that these resources come from the savings of households, it refers to relatively prosperous households - in this context only the top few deciles need to be considered. The more developed the economy, the more deciles become relevant. Policy designed to mobilize a larger volume of funds for intermediation should therefore be directed to matters that affect behaviour of the upper deciles. Such policies would include those affecting political confidence, macroeconomic stability and expected after-tax returns on financial savings. 
A rather different set of policies comes to the fore in seeking to expand the number of households with access. These include regulatory design for microfinance institutions, ensuring that measures designed to protect consumers against loss do not impose costs so heavy as to deter entry into this low end of the market, characterized by low margins but potentially high volume. Current policy concerns in advanced economies on suboptimal allocation of the household portfolio remain of secondary importance in most developing countries. Instead, legal, regulatory and tax policies affecting the cost and availability to lower income households, of such products as insurance and home construction lending, loom large on the policy agenda.

The remainder of the paper is divided into five sections. The first presents some known statistical regularities about the variation across income groups and countries of household financial asset holdings. Section 2 discusses the channels through which household financial asset holdings affect national growth and poverty. Section 3 turns to the question of how widespread is access by households to financial assets, presenting new data for over 150 countries, and using this data to assess whether such access per se helps to reduce aggregate poverty. Section 4 briefly discusses household choice among different financial assets. Concluding remarks are in Section 5.

\section{Household financial assets: how holdings vary across income groups and countries}

Our knowledge of the pattern of household financial asset holdings varies greatly by country. The US has the most comprehensive and apparently reliable data in the form of the triennial Survey of Consumer Finances, preliminary results of the most recent wave from 2004 have just been published by the Federal Reserve Board (Bucks et al. 2006, updating Aizcorbe et al. 2003). Earlier waves of the US survey are thoroughly compared with data for four other advanced economies, Germany, Italy, Netherlands and the UK, in Guiso et al. (2002). Other advanced countries for which data are available include Korea and Japan. Data for developing countries are, however, very sketchy and current data collection exercises in this area are focused more on measuring access or participation than on quantifying asset magnitudes. In this review we draw on much more limited data mainly on savings balances collected in general household surveys for Ghana, Jamaica and Vietnam, on a 2003 module on household assets and liabilities in India collected as part of the 59th National Sample Survey (NSSO 2005), on a survey of investment in stock market assets in India (Kar et al. 2003) and on a household survey carried out in 2002 in rural and urban areas in China by CASS (Li and Zhao 2006). They show some commonalities with other advanced economies, but also some differences which may be due to survey limitations.

Despite the sketchiness of data sources, some stylized facts can be adduced by reasonable extrapolation and interpolation from what we do have. One cannot, of course, rely wholly on the assumption that cross-sectional patterns within economies- 
variations in the pattern of asset allocation by such characteristics as age, education and wealth - can be extrapolated from the rich countries for which we do have crosssectional data to the poor. Nevertheless, some of those patterns likely do hold up qualitatively (and we will show the extent to which some of them are confirmed in our handful of developing countries for which some data are available) and the patterns can be scaled to the aggregate magnitudes for which data are available in the poor countries.

Financial assets 4 represent a sizable proportion of the aggregate non-human wealth of households — over 50 per cent in Norway (Jäntti and Sierminska 2006) and over 40 per cent in the US, even if we take the results of household surveys, which may disproportionately understate financial assets if compared to data from national balance sheets computed from national accounts sources (Davies et al. 2006). The share of financial assets in total wealth tends to increase with mean income. For Australia, Canada, Germany, Italy, the Netherlands and Sweden, the figure obtained from household surveys is about 30 per cent (Guiso et al. 2003; Jäntti and Sierminska 2006);5 in China it is 22 per cent (Li and Zhao 2006), in Korea only 17 per cent (Yoo 2005) and in India about 4 per cent (NSSO 2005; Subramanian and Jayaraj 2006).

Household financial liabilities also need to be considered for a rounded view; indeed, it would be very artificial to look only at the asset side when it comes to financial assets and liabilities, since both are endogenous and thought to be determined in large part by the same explanatory variables. In aggregate, household financial liabilities amount to as much as 30 per cent of gross household financial assets in the US, where consumer and household finance is very well developed. Indeed, for all but about the top decile of the income distribution in that country, borrowing exceeds gross financial asset holdings. In other words, net financial assets for the lower 90 per cent are negative. The largest category of debt is mortgage and home equity debt, reflecting the fact that a homeowner's residence can represent valuable collateral. Installment credit (mainly related to the purchase of automobiles and other household durables) and credit card debt are also used in rich countries, but amount to smaller sums.

Borrowing possibilities for low-income households from formal intermediaries are more limited in less advanced economies. In these countries, middle class employee households may borrow unsecured, but often under arrangements whereby servicing charges are deducted from wage payments by the employer and remitted to the financial intermediary.

\footnotetext{
4 See Appendix 1 for a description of how financial assets are defined.

5 The figure for Japan has been highly volatile in view of the housing boom and bust of the 1980s and 1990s (Iwaisako 2003).
} 


\subsection{Concentration of financial asset holdings}

Just as the share of financial assets in the total increases with mean income across countries, the distribution of financial wealth within advanced economies appears to be more concentrated than non-financial non-human (and than human wealth or income; see Figure 1 for the US data). This may be less true in developing countries. For example, Indian survey data suggest that the share of financial in non-human wealth is not monotonically increasing in wealth (Subramanian and Jayaraj 2006). The relatively undeveloped equity markets-limiting the availability of sophisticated financial claims on the local capital stock-the importance of landholding and the fact that most businesses are closely-held would be contributing factors to this difference. In China too, financial wealth as surveyed is not more concentrated than other wealth ( $\mathrm{Li}$ and Zhao 2006), however China's status as a transition economy must be taken into account in considering the relevance of this observation for other countries. Nevertheless, it is true for all countries that the bulk of financial assets is held by relatively wealthy households. Indeed, the bottom half of the wealth distribution in the USA holds no more

Figure 1: Characteristics of the distribution of financial and other household asset holdings, USA 2001
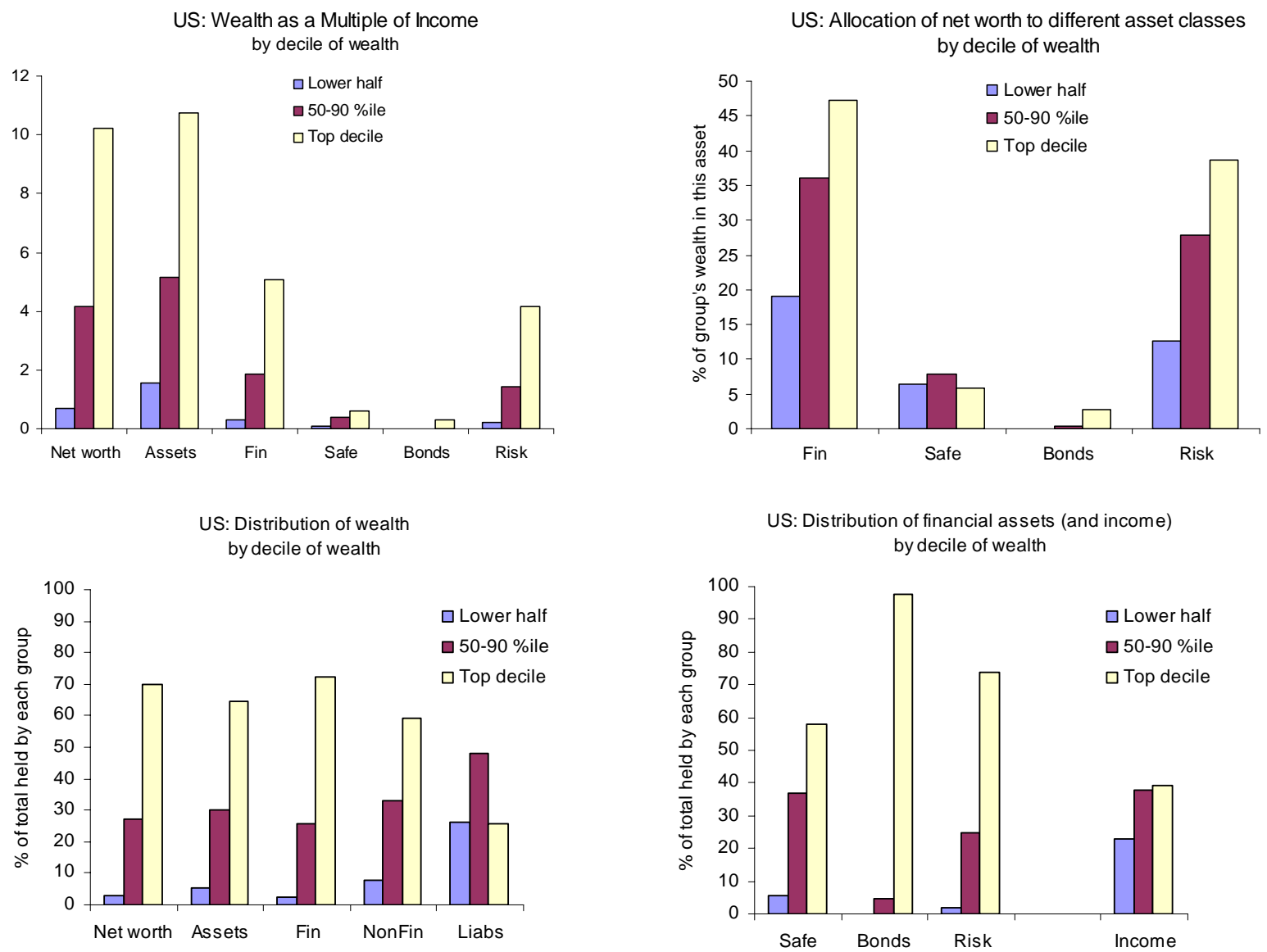

Source: Based on data in Kennickell (2003). Example, (a) net worth of the top wealth decile exceeds 10 times their income, (b) top decile holds 47 peer cent of its wealth in financial assets, (c) top decile holds 70 percent of systemwide net worth. 
than 3 per cent of the system's financial assets. The same group holds about 4 per cent of the risk-free assets and 2 per cent of the risky assets.

Given the fact that a much larger fraction of the population in poor countries holds no financial assets at all, and given that income is in most cases more unequally distributed in developing countries, it would seem likely that the share of financial assets held by the lower deciles would be even lower in the typical low- or middle-income country. In other words, concentration of financial asset ownership is surely even higher in poor countries. This conjecture is not, however, strongly confirmed by the available survey data. In India-where the data on risk-free financial assets includes cash holdings-the bottom half of the wealth distribution hold about 6 per cent of risk-free assets, and less than 3 per cent of risky assets (shares). For three other countries, Ghana, Jamaica and Vietnam (Figure 3), in the absence of wealth deciles, we calculated mean savings balances for expenditure/consumption deciles. One expects a higher percentage of total savings held by the bottom half of the expenditure decile than on the wealth decile, but the figures obtained are surprisingly high. The Ghana and Vietnam surveys respectively show 11 and 10 per cent of reported savings balances being held by the bottom half of the expenditure distribution of the surveyed households. 6 It may well be that these surveys do not capture the top end of the distribution as well as the specialized financial asset surveys for advanced economies, given that their purpose is not mainly to cover wealth issues. We prefer to discount these particular findings, and rely on the patterns observed more reliably in advanced economies to conclude that policy directed at mobilizing investable funds through the issue of financial assets can safely ignore the lower quartiles of the wealth distribution at least as far as the aggregate sums mobilized are concerned. 7

Taking account also of the net financial indebtedness of all but the highest income groups, it seems that the net provision of investable funds from the household to the business and government sectors depends essentially on the top decile of the income distribution - for the US, this group contributes 91 per cent of net household financial assets (as compared with 72 per cent of gross household financial assets).

\footnotetext{
6 For Jamaica, the figure is even higher at 35 per cent. However the Jamaica data is marred by a failure in the coding for these questions to distinguish between non-responding households and respondents who report zero balances. The percentage reporting positive balances actually declines from about 30 per cent in the middle quartiles of expenditure to 17 per cent for the top 5 per cent, strongly suggesting a sharp increase in non-response at the top of the income distribution for this country.

7 That is not to say that banks will necessarily ignore the smaller depositor. Handling small deposits is costly, but potentially more profitable per dollar transacted. There is value at the 'bottom of the pyramid' for intermediaries that can master the necessary cost efficiencies. But the volume of resources mobilized is negligible in terms of aggregate national intermediation.
} 
For advanced economies, the increased share of financial assets in total wealth is more a function of increased participation 8 as we go up the income scale, more than an increase in the value of holdings conditional on participation. Interestingly, for Ghana a similar pattern appears for savings balances - the proportion of households reporting some savings balances does increase with income/expenditure, and the unconditional elasticity is about 1.8 , but the ratio of savings balances to expenditure remains broadly constant conditional on reporting any holdings. However, in Vietnam, where very high participation is reported for all expenditure quartiles this is not true; the elasticity of savings balances to expenditures is about 1.7 for those households reporting some balances. 9

\subsection{Households' share of aggregate financial assets}

Wealthy households hold a sizable fraction of aggregate bank deposits. The household sector in aggregate holds more than 63 per cent of total deposits at financial intermediaries in the USA, and 80 per cent of deposits from non-financial nongovernment domestic sectors. 10 For the eurozone, comparable percentages are reported: 60 per cent and 78 per cent respectively. 11 Individuals hold 43 per cent of all resident deposits in the UK, a figure that rises to over two-thirds if deposits of financial institutions and public administration are excluded.12 Just over a half of the large deposit base of Chinese financial institutions is in the form of household savings deposits.13 In Egypt, households account for 78 per cent of total deposits.14 In the Eastern Caribbean Currency Union, household deposits are 60 per cent of the total, or 68 per cent if financial and government deposits are excluded. In addition, households' claims on managed funds, combined with their direct holdings, can be considered to finance a large share of traded equities in the more advanced economies.

8 By participation is meant whether or not holdings are non-zero. Fixed costs, including those of acquiring information, helps explain why households hold only a subset of available assets. King and Leape (1998) estimate a decision model incorporating such costs as well as non-negativity constraints on the US SCF data.

9 The data for Jamaica is again out of synch; the elasticity here is below 0.7 .

10 Tables L204 and L205 of www.federalreserve.gov/releases/z1/current/z1r-4.pdf. The percentages include savings and time deposits as well as checking accounts and currency.

11 Households accounted for $€ 4.3$ trillion of a total of domestic non-government deposits of $€ 7.0$ trillion in eurozone monetary financial intermediaries at end-2005. Non-government nonfinancial deposits amounted to €5.6 trillion (https://stats.ecb.int/stats/download/weas02_05/weas02_05/weas02_05.pdf).

12 www.bankofengland.co.uk/statistics/abl/2005/dec/tableb.pdf.

13 Including demand deposits and time deposits (www.pbc.cov.cn, Table: Sources and Uses of Credit Funds of Financial Institutions).

14 www.cbe.org.eg/timeSeries.htm. 


\subsection{Offshore assets and liabilities}

Although households, like other investors, tend to display a degree15 of home preference that discourages cross-border holdings of financial assets, nevertheless, reasons of political risk and tax avoidance can provide an important push in the opposite direction, resulting in capital flight and the holding of sizable and often covert offshore assets. Inevitably, it is difficult to measure the scale and pattern of this flight capital, but it is undoubtedly large (Hanson 2003 and references). Omission of offshore holdings will inevitably tarnish any analysis of household financial assets in developing countries.

\section{Household financial assets and growth}

Numerous econometric studies have established a causal link between financial depth and GDP growth.16 The indications are that it is through its influence on the productivity of investment, rather than on its magnitude, that bank intermediation exerts its pro-growth effect, at least in higher income economies. It is the aggregate stock of bank credit to private sector borrowers, rather than the aggregate stock of money, that has been found to be the most robust explanatory variable in these regression analyses. But without mobilized funds for onlending, the banks would not be able to increase the volume of credit. Given the importance of household asset accumulation in easing the challenge for local banks to mobilize funds for onlending, household financial asset holdings do make a potentially significant indirect contribution to growth. 17 It needs to be underlined that this extra link in the chain (from money to credit) is not a very tight one. For example, banks in much of sub-Saharan Africa hold sizable excess reserves, either finding insufficient bankable lending opportunities to deploy the deposits which they have mobilized, or preferring to invest in high-yielding government securities in cases where domestic financing of government deficits in effect crowds out private lending; in this case additional household deposits are unlikely to be onlent. Furthermore, other countries have experienced the opposite phenomenon, where banks draw on external credit lines to finance more private lending than could be funded out of domestic resources - direct offshore borrowing by larger enterprises has also been observed in those cases. Nevertheless in broad terms (and in an echo of the HoriokaFeldstein savings-investment correlation across countries), banking depth on the deposit and private credit side remain strongly correlated across countries, suggesting that there

15 Albeit diminishing, cf. Huizinga and Jonung (2005)

16 The finance and growth literature is surveyed in detail by Levine (2005), and summarized more briefly by Honohan (2004a). There remains some doubt as to whether this effect is more important at low or intermediate levels of income, or of financial development (Rioja and Valev 2004; Aghion et al. 2005)

17 The household dimension often not taken into account, so it is overall financial depth and not the household's share that is considered in the literature on finance and growth. 
is a link even if it is not a rigid one (data for 138 countries are shown in Figure 4a: the correlation is +0.71$) .18$

If the poor have limited access to credit, might this imply that financial development is pro-rich, disproportionately benefiting the wealthy? Or is it for outsiders and newcomers that a well-developed financial system most provides opportunities in terms of smoothing consumption, diversifying risk and overcoming indivisibilities in investment. An interesting but rather rarified theoretical literature has explored a variety of channels through which financial development could affect the evolution of income distribution. Generally speaking, these models pivot on credit constraints and on such aspects as collateral as a prerequisite for credit, and by such considerations as the possibility that improvements in financial intermediation will be seized first by the already wealthy. There has been no professional consensus on which of the various models, with their mutually contradictory conclusions, is most likely to fit reality. Empirical evidence is accumulating, though, that financial development appears to be correlated not only with aggregate income growth, but also with lower poverty, even conditional on average income levels. Somewhat ironically, this seems to be the case more for financial depth indicators than for financial access indicators (see below).

$\mathrm{Li}$ et al. (1998) were the first to look at this kind of issue in a cross-country econometric framework. They found that income inequality (Gini coefficient) was lower in crosssectional regressions with deeper financial systems. Honohan (2004a: 1-37) showed that absolute poverty (proportion of the population below the \$1-a-day or \$2-a-day poverty line) was lower in deeper financial systems, even conditional on the mean income level achieved by the non-rich, and these findings are confirmed on an updated and expanded data set in Table 2. Beck et al. (2004) looked at income growth rates of the poor and found that they were disproportionately high where financial intermediary development was deep. So there is a double effect on poverty-finance boosts mean income growth and it also promotes a more equal income distribution. 19

So far, this apparent pro-poor twist to financial depth remains something of a black box. It could reflect the mechanism proposed by Rajan and Zingales (2003), whereby a developed financial system is one where availability of credit undermines the economic power of incumbent elites, thereby generally diffusing development more widely and opening more opportunities. More household saving in financial assets fuels this credit availability and represents an important anti-poverty force.

\footnotetext{
18 The outliers are (a) countries with a large nonbank sector (like the US or Norway) funded with liabilities that are not included in the liquid liabilities definition used for the deposit side; (b) offshore financial centers (like Malta) holding sizable foreign assets; (c) Countries with relatively large lending by the banking system to the government (like Japan).

19 These findings receive a nice confirmation from the results of Dehejia and Gatti (2005), who found a favourable cross-country effect of financial development on child labour.
} 


\section{$3 \quad$ Does access to a bank account help reduce poverty?}

Casting our eyes to the bottom of the pyramid, we need to remind ourselves that, for lower income groups, it is not a question of how much financial assets they choose to hold, and even less a question of how much they choose to borrow from the financial system. These households encounter barriers to accessing financial services. 20 In the advanced economies, this has led to a growing debate around the issue of financial exclusion. It is noted that a small but multiply deprived group-perhaps 10 per cent of the adult population-do not have access to financial services such as a transactions account, or even a savings account, much less a loan from a formal intermediary or an insurance policy. In some cases product features, such as a high minimum cover for an insurance product, or heavy penalties for unauthorized overdrafts (hard for poor people to avoid if they are using checking accounts), or having a fixed address as a prerequisite to open an account, represent material obstacles to use of such products. In other cases customers may be screened-out because of risk characteristics. Or rationalization of branches and service points may result in many poor customers having too far to travel to a branch to make an account worthwhile. Given the increasing extent to which full participation in economic life in the advanced economies depends on having an account at a financial intermediary, and given the material extra costs often imposed on nonaccount holders, several countries have adopted policies in recent years to reduce financial exclusion (Porteous 2004; Carbo et al. 2005).

In low- and middle-income countries, though, exclusion is normal for the bulk of the population, hence it becomes more natural to speak of broadening access to financial services rather than elimination of exclusion as the immediate goal. The exploding microfinance movement is driven by this motivation (Armendariz de Aghion and Morduch 2005; Honohan 2004b; Robinson 2001). Microfinance pioneers have emphasized the very high rates of return that can be earned by the poor and the nearpoor, especially in urban and peri-urban settings, resulting in a high demand for borrowings even at high interest rates. Some microfinance institutions work on a creditonly basis, funding themselves from charitable donors and other sources; some employ forced savings elements to the loan scheme. The modern trend is to emphasize deposits as well as loans as key tool for efficient financial management, whether they represent precautionary savings, or a means of accumulating capital. Transactions accounts are also important for receiving and making internal and international remittances between family members. And micro insurance is beginning to be a significant element in the microfinance movement.

20 Including transactions services — an important dimension for such households which can be associated with the holding of balances in transactions accounts, but which will not be further discussed in this paper. 
Does access to financial services through deposit or loan accounts reduce poverty? Numerous anecdotes illustrate paths to relative prosperity being paved by such financial services. However, there is typically a large element of selection bias, both at the level of the individual client (with the more energetic likely to experience growing loan and deposit balances) and at the level of the village selected for establishment of a microfinance institution (sometimes this is a negative bias, as charitable sponsors seek out the more deprived villages). Furthermore, there can be displacement effects, with non-beneficiaries of microfinance suffering in local markets from the beneficiaries. Despite an extensive quasipromotional literature, detailed microeconometric analyses are, for these technical reasons, surprisingly non-committal about whether direct financial access has a major effect in reducing poverty (Honohan 2004b).

What can be said at the macro level? Addressing this question evidently requires a cross-country data series on access. There are many dimensions to financial access, but to simplify matters, given the shortage of data, it is preferable to concentrate on one summary indicator. The most widely accepted indicator is the percentage of adults that have any type of account (including all types of transactions, savings or loan accounts) at a bank or other formal financial intermediary (World Bank 2005). How many people in developing countries have access to a bank or other formal financial intermediary account? This empirical question is the subject of vigorous current investigation. Piecing together elements from several other studies (especially Beck et al. 2005; Christen et al. 2004; Peachey and Roe 2006), Appendix 2 details the methodology of a new composite indicator available for over 150 countries (Table 1; Figure 5) and which has the merit of drawing on available data on the number of accounts in commercial banks, savings banks and various forms of microfinance institutions, and the average size of these accounts, as well as on the results of household surveys for the much more limited number of countries for which those are available.

While recognizing the shortcomings of the imputation procedures used to construct the composite indicator, as well as the limitations (outlined in the appendix) of the underlying data sources, the resulting dataset is nevertheless interesting. Appropriate econometric techniques can limit the consequences of random error.

Returning then to the question of whether financial access reduces poverty, we may use the new access data to obtain a macro cross-country perspective on this issue. Earlier work (using the CGAP data also described in Appendix 2) failed to find any significant cross-country correlation between the density of microfinance accounts and poverty rates (Honohan 2004b). But given the extensive differences between the old data and the new composite series, it is worth repeating the experiment. In fact (Table 2) using any of the variants of the new data series presented in Appendix 2, we do find that access is correlated with poverty rates. This is true even of the microfinance-only data (referred to in the Appendix as the WSBI series-see regression 2.D). It is also true of the synthetic access percentages (2.E) or the composite series (2.F). But access 
percentages are, of course, strongly correlated with per capita income (Figure 6), 21 and since the latter is highly correlated with poverty rates, the more interesting question is whether access remains significant in a regression which also includes per capita income. In fact, when per capita income and other controls found to be significant in earlier work (see 2.A-C) are added to the specification, none of the access series retains significance (2.G).

Given the numerous deficiencies of the aggregate access data series, these negative macro cross-country results should not be taken as proving that access has little effect, but neither do they provide any strong evidence in favour of that hypothesis. Besides, the equation is clearly under-specified, the omission of relevant variables could mask or bias the estimated role of access. For instance, access might be more effective in the presence of other elements of the financial infrastructure such as credit registries or effective protection of property rights (Johnson et al. 2002; Djankov et al. 2006), or if financial liberalization is more advanced (Waldenström and Vlachos 2005). The strength and presence of informal credit channels could also be a factor. Several other control variables reflecting for example education and labour market conditions deserve to be included also. Future work will report the results of further analysis along these lines.

21 In a regression of data on the summary access indicator for 147 countries, per capita income explains 60 per cent of cross country variation. After exclusion of six outliers, Hong Kong, Lebanon, Luxembourg, Macao, China and United Arab Emirates, this jumps to 73 per cent. It is likely that these six outliers should be omitted from most analyses with this data. 
Table 1: Composite measure of access to financial services

\begin{tabular}{|c|c|c|c|c|c|c|c|c|c|c|c|}
\hline Albania & $\mathrm{b}$ & ALB & 34 & Germany & s & DEU & 97 & Panama & & PAN & 46 \\
\hline Algeria & & DZA & 31 & Ghana & & GHA & 16 & Papua New Guinea & $b$ & PNG & 8 \\
\hline Angola & & AGO & 35 & Greece & s & GRC & 83 & Paraguay & & PRY & 30 \\
\hline Antigua \& Barbuda & & ATG & 48 & Grenada & & GRD & 37 & Peru & & PER & 26 \\
\hline Argentina & $b$ & ARG & 28 & Guatemala & s & GTM & 32 & Philippines & & $\mathrm{PHL}$ & 26 \\
\hline Armenia & s & ARM & 9 & Guinea & & GIN & 20 & Poland & s & POL & 66 \\
\hline Austria & $\mathrm{s}$ & AUT & 96 & Guyana & s & GUY & 14 & Portugal & $s$ & PRT & 84 \\
\hline Azerbaijan & & AZE & 17 & Haiti & & HTI & 15 & Romania & & ROM & 23 \\
\hline Bahamas, The & & $\mathrm{BHS}$ & 53 & Honduras & B & HND & 25 & Russian Federation & & RUS & 69 \\
\hline Bangladesh & & BGD & 32 & Hong Kong, Chn & & HKG & [38] & Rwanda & & RWA & 23 \\
\hline Barbados & & BRB & 56 & Hungary & S & HUN & 66 & Samoa & & WSM & 19 \\
\hline Belarus & & BLR & 16 & India & & IND & 48 & Saudi Arabia & & SAU & 62 \\
\hline Belgium & s & BEL & 97 & Indonesia & & IDN & 40 & Sao Tome \& Principe & & STP & 15 \\
\hline Belize & & BLZ & 46 & Iran, Isl. Rep. & & IRN & 31 & Senegal & & SEN & 27 \\
\hline Benin & & BEN & 32 & Iraq & & IRQ & 17 & Seychelles & & SYC & 41 \\
\hline Bermuda & & $\mathrm{BMU}$ & 48 & Ireland & s & IRL & 88 & Sierra Leone & & SLE & 13 \\
\hline Bhutan & & BTN & 16 & Italy & s & ITA & 75 & Singapore & $b$ & SGP & 98 \\
\hline Bolivia & & $\mathrm{BOL}$ & 44 & Jamaica & & JAM & 59 & Slovak Republic & & SVK & 83 \\
\hline Bosnia \& Herzeg. & & $\mathrm{BIH}$ & 17 & Jordan & $b$ & JOR & 37 & Slovenia & & SVN & 97 \\
\hline Botswana & & BWA & 47 & Kazakhstan & & KAZ & 48 & Solomon Islands & & SLB & 15 \\
\hline Brazil & s & BRA & 43 & Kenya & s & KEN & 10 & South Africa & & ZAF & 46 \\
\hline Bulgaria & s & BGR & 56 & Korea, Rep. & & KOR & 63 & Spain & s & ESP & 95 \\
\hline Burkina Faso & & BFA & 26 & Kyrgyz Republic & & KGZ & 1 & Sri Lanka & & LKA & 66 \\
\hline Burundi & & $\mathrm{BDI}$ & 17 & Latvia & & LVA & 64 & St. Kitts and Nevis & & KNA & 49 \\
\hline Cambodia & & $\mathrm{KHM}$ & 20 & Lebanon & $b$ & LBN & [79] & St. Lucia & & LCA & 40 \\
\hline Cameroon & & CMR & 24 & Lesotho & & LSO & 17 & St. Vincent \& Gren. & & VCT & 45 \\
\hline Cape Verde & & CPV & 52 & Liberia & & LBR & 11 & Sudan & & SDN & 15 \\
\hline Cent African Rep. & & CAF & 19 & Libya & & LBY & 27 & Suriname & & SUR & 32 \\
\hline Chile & & $\mathrm{CHL}$ & 60 & Lithuania & s & LTU & 70 & Swaziland & & swz & 35 \\
\hline China & & $\mathrm{CHN}$ & 42 & Luxembourg & s & LUX & 99 & Sweden & s & SWE & 99 \\
\hline Colombia & s & $\mathrm{COL}$ & 41 & Macao, China & & MAC & [14] & Switzerland & $b$ & $\mathrm{CHE}$ & 88 \\
\hline Comoros & & $\mathrm{COM}$ & 20 & Macedonia, FYR & & MKD & 20 & Syrian A.R. & & SYR & 17 \\
\hline Congo, Rep. & & COG & 27 & Madagascar & & MDG & 21 & Tajikistan & & $\mathrm{TJK}$ & 16 \\
\hline Costa Rica & & $\mathrm{CRI}$ & 29 & Malawi & & MWI & 21 & Tanzania & & TZA & 5 \\
\hline Cote d'Ivoire & & CIV & 25 & Malaysia & $\mathrm{b}$ & MYS & 57 & Thailand & & THA & 59 \\
\hline Croatia & & HRV & 42 & Mali & & MLI & 21 & Timor-Leste & & TMP & 13 \\
\hline Cuba & & CUB & 45 & Malta & s & MLT & 90 & Togo & & TGO & 28 \\
\hline Cyprus & s & CYP & 85 & Mauritania & & MRT & 16 & Trinidad \& Tobago & & TTO & 53 \\
\hline Czech Republic & $\mathrm{s}$ & CZE & 85 & Mauritius & $b$ & MUS & 60 & Tunisia & & TUN & 42 \\
\hline Denmark & s & DNK & 99 & Mexico & s & MEX & 25 & Turkey & $b$ & TUR & 49 \\
\hline Dominica & & DMA & 66 & Moldova & & MDA & 13 & Uganda & & UGA & 20 \\
\hline Dominican Rep. & & DOM & 29 & Mongolia & & MNG & 30 & Ukraine & & UKR & 24 \\
\hline Ecuador & s & ECU & 35 & Morocco & & MAR & 39 & United Arab Emirates & $\mathrm{b}$ & ARE & [33] \\
\hline Egypt & & EGY & 41 & Mozambique & & MOZ & 12 & United Kingdom & s & GBR & 91 \\
\hline El Salvador & & SLV & 26 & Myanmar & & MMR & 19 & United States & s & USA & 91 \\
\hline Eritrea & & ERI & 12 & Namibia & s & NAM & 28 & Uruguay & & URY & 42 \\
\hline Estonia & s & EST & 86 & Nepal & & NPL & 20 & Uzbekistan & & UZB & 16 \\
\hline Ethiopia & & ETH & 14 & Netherlands & & NLD & 100 & Venezuela & $\mathrm{b}$ & VEN & 28 \\
\hline
\end{tabular}




\begin{tabular}{|c|c|c|c|c|c|c|c|c|c|c|c|}
\hline Fiji & $\mathrm{b}$ & $\mathrm{FJI}$ & 39 & Nicaragua & s & NIC & 5 & Vietnam & & VNM & 29 \\
\hline Finland & s & FIN & 99 & Niger & & NER & 31 & West Bank \& Gaza & & WBG & 14 \\
\hline France & $\mathrm{s}$ & FRA & 96 & Nigeria & & NGA & 15 & Yemen, Rep. & & YEM & 14 \\
\hline Gabon & & GAB & 39 & Norway & $b$ & NOR & 84 & Yugoslavia, FR & & YUG & 21 \\
\hline Gambia & & GMB & 21 & Oman & & OMN & 33 & Zambia & & ZMB & 15 \\
\hline Georgia & & GEO & 15 & Pakistan & $b$ & PAK & 12 & Zimbabwe & b & ZWE & 34 \\
\hline
\end{tabular}

Note: 's' means household survey data used; 'b' means fitted data using bank deposit numbers and not WSBI numbers. [Square bracketed data are considered less reliable]. This is Mark Ilc version of the data series: As more refined information on specific countries is obtained, it is envisaged that this series will be updated.

Source: Author's calculations based on Beck et al. (2005), Christen et al (2004), Claessens (2005), European Commission (2005), Peachey and Roe (2006). For definitions and method see Appendix 2.

\section{Allocation between different assets}

Turning to the composition of the household financial portfolio, one distinctive stylized fact is that the rich hold a much riskier financial asset portfolio.22 In making this judgment, we rely on the conventional classification that treats bank deposits (and other liquid assets largely free of default risk such as mutual funds solely invested in shortterm money market assets and certain government-sponsored savings schemes) as largely risk-free.23 US data (Figure 1) suggests that these display a wealth elasticity of close to unity.24 Though subject to market risk, government bonds are also often classified with the risk-free; lower wealth deciles do not hold much of these, but even when they are included with the other risk-free assets, this broader category still displays a wealth elasticity little more than unity (constant share of wealth held in this form). Up to a certain level,25 other risky financial assets have a wealth elasticity much higher than unity - this reflects the declining share of total wealth held in non-financial form as wealth increases. Extrapolating these observations to conditions in low-income countries, the share of risky financial assets in the national totals is likely to be smaller in poor countries. This indeed is confirmed by the observation that the ratio of aggregate national bank deposits to market capitalization is negatively correlated with per capita income - though the correlation is rather weak when attention when data is restricted to developing countries, because of outliers such as Israel, Jamaica and Slovenia (Figure $4 b)$.

22 Carroll (2002) has shown that a strong bequest motive could explain not only higher savings rates for high income households but also a higher risk-tolerance. Carroll also notes that rich households hold a relatively high share of non-financial business equity. He suggests that this is due to capital market imperfections inducing owners of technology or other productive assets to invest in their own enterprises An alternative explanation is that true total Haig-Simon income from non-financial wealth is higher than measured. After all, what is wealth but capitalized Haig-Simon income?

23 Even though subject to inflation risk as well as (in less advanced economies) a small but sometimes not insignificant default risk.

24 Inferred from data on asset multiples of income for deciles of wealth in Kennickell (2003).

25 To about the $90^{\text {th }}$ decile of wealth in the US data: non-financial business equity assets represent an increasing share of the portfolios of the very rich. 
The pattern of increasing risk as wealth increases appears to be driven mainly by higher participation by rich households in the riskier assets. In other words, a higher proportion of wealthy households hold risky financial assets, but among households with financial assets there is relatively little systematic variation in the ratio of risky financial assets to other assets as wealth increases. This can be seen in Figure 2 for six advanced economies (based on Guiso et al. 2002, compare their Tables 1.5 and 1.7), and for Korea. If this can be extrapolated to low-income countries, then it implies that patterns of ownership can be inferred from participation rates for different assets and products. Participation data for risky financial assets are available for India (Kar et al. 2003) and it also shows a strong upward trend with income (Figure 2). Conditional on some holdings of risky assets, the share of risk in total financial assets rises slightly with income in China. It seems safe to assume that the unconditional share of risky assets increases with wealth in both China and India. Note that participation rates are much lower for all quintiles in India than for the advanced economies shown - as is surely the case in all developing countries. But is household portfolio allocation efficient? There are various reasons to suppose that it is not. For instance, it is hard to rationalize the lack of diversification in most household portfolios. 26 The existence of an equity premium has contributed to a perception that risky assets form too low a share in household portfolios. Other kinds of portfolio allocation error are also conjectured, such as reliance on fixed-interest mortgages when choice of floating might place the household on a higher indifference curve. Reviewing this literature for the US, Campbell (2006) concludes that 'many households are reasonably effective investors, but a minority make significant mistakes,' and that there may be a persistent cross-subsidy from naïve to sophisticated households.

\footnotetext{
26 For example, Kelly (1995) showed that the median US investor held just one equity stock.. More recently, Goetzmann and Kumar (2005) showed that, while diversification is increasing among the clients of a large US brokerage, many are still demonstrably insufficiently diversified and forgo substantial returns on a risk-adjusted basis, even after allowing for transactions costs. Bergstresser and Poterba (2004) discuss tax inefficient portfolio allocation by US households.
} 
Table 2: Poverty and financial access

\begin{tabular}{|c|c|c|c|c|c|c|c|c|c|c|c|c|c|c|}
\hline \multirow[t]{2}{*}{ Equation: } & \multicolumn{2}{|l|}{ 2.A } & \multicolumn{2}{|l|}{ 2.B } & \multicolumn{2}{|l|}{ 2.C } & \multicolumn{2}{|l|}{ 2.D } & \multicolumn{2}{|l|}{ 2.E } & \multirow{2}{*}{$\begin{array}{r}2 . F \\
\text { Coeff. }\end{array}$} & \multicolumn{3}{|c|}{$2 . G$} \\
\hline & Coeff. & t-Stat & Coeff. & $\mathrm{t}-$ Stat & Coeff. & t-Stat & Coeff. & $\mathrm{t}$-Stat & Coeff. & t-Stat & & t-Stat & Coeff. & t-Stat \\
\hline Constant & 173.6 & $\star \star 11.6$ & 170.6 & **12.8 & 137.8 & $\star \star 8.5$ & 31.4 & $\star * 6.7$ & 94.5 & $* * 6.1$ & 61.1 & $\star * 5.7$ & 140.0 & $\star \star 8.5$ \\
\hline GNI per cap (log) & -18.8 & $\star \star 10.4$ & & & & & & & & & & & & \\
\hline GNI per cap lower 90\% (log) & & & -19.2 & $\star \star 11.4$ & -17.5 & $* \star 10.4$ & & & & & & & 23.4 & $\star * 8.8$ \\
\hline Share of top $10 \%$ & & & & & 0.574 & **3.3 & & & & & & & 0.948 & $\star \star 3.1$ \\
\hline Access (log) & & & & & & & -4.4 & $\star \star 2.7$ & -22.1 & $\star \star 4.8$ & -12.4 & $\star \star 3.9$ & -2.0 & 0.8 \\
\hline Which measure? & & & & & & & WSBI & & Synth & & Comp & & Comp & \\
\hline R-squared / NOBS & 0.546 & 91 & 0.598 & 89 & 0.643 & 89 & 0.079 & 88 & 0.212 & 88 & 0.151 & 89 & 0.645 & 87 \\
\hline Adjusted R-squared & 0.541 & & 0.593 & & 0.634 & & 0.068 & & 0.203 & & 0.141 & & 0.632 & \\
\hline S.E. of regression & 15.2 & & 14.2 & & 13.5 & & 21.9 & & 20.3 & & 21.0 & & 13.7 & \\
\hline Log likelihood & -375.7 & & -361.5 & & -356.2 & & -395.5 & & -388.7 & & -396.2 & & -348.8 & \\
\hline
\end{tabular}

Note: This table shows regressions relating the $\$ 1$ per day poverty percentage to financial access percentages across countries. ** and * indicate significance at the $1 \%$ and $5 \%$ levels, respectively. Cross section: all available countries: Note GNI per cap is measured at PPP ; WSBI is the data in Peachey and Roe (2006); Synth(etic) is the predicted share using the estimated regression $\mathrm{J}$ in Table A1: Comp(osite) is based on household survey data where available, otherwise Synth (see Appendix 2-Mark Ila of the composite series was used here).

Source for poverty and inequality measures: GPID; source for GNI: WDI.

Table 3: Use of different financial products, EU countries, 2005, \%

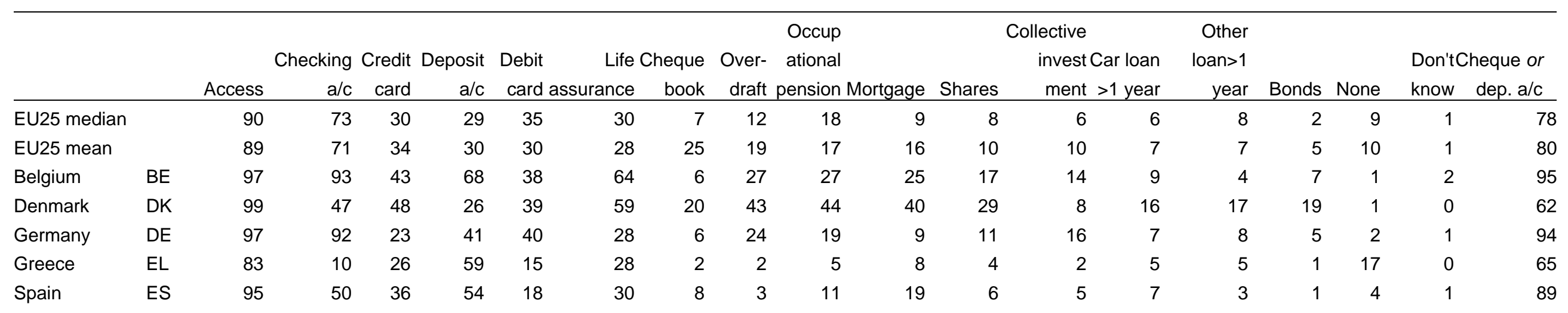




\begin{tabular}{|c|c|c|c|c|c|c|c|c|c|c|c|c|c|c|c|c|c|c|c|}
\hline France & FR & 96 & 87 & 62 & 21 & 35 & 10 & 75 & 38 & 11 & 23 & 8 & 10 & 10 & 8 & 2 & 2 & 2 & 89 \\
\hline Ireland & $\mathrm{IE}$ & 88 & 57 & 40 & 36 & 36 & 42 & 29 & 16 & 19 & 22 & 10 & 4 & 23 & 12 & 5 & 11 & 1 & 72 \\
\hline Italy & IT & 75 & 62 & 20 & 9 & 10 & 6 & 24 & 4 & 4 & 6 & 6 & 6 & 3 & 3 & 4 & 24 & 1 & 70 \\
\hline Luxembourg & LU & 99 & 74 & 65 & 29 & 38 & 59 & 9 & 39 & 18 & 25 & 18 & 16 & 17 & 11 & 6 & 1 & 0 & 85 \\
\hline Netherlands & NL & 100 & 95 & 43 & 30 & 45 & 65 & 7 & 4 & 26 & 49 & 21 & 23 & 3 & 3 & 7 & 0 & 0 & 96 \\
\hline Austria & AT & 96 & 73 & 28 & 56 & 39 & 61 & 5 & 31 & 25 & 5 & 7 & 6 & 9 & 11 & 4 & 2 & 2 & 84 \\
\hline Portugal & PT & 84 & 74 & 20 & 12 & 21 & 43 & 35 & 4 & 6 & 10 & 4 & 1 & 4 & 3 & 2 & 14 & 2 & 77 \\
\hline Finland & $\mathrm{FI}$ & 99 & 82 & 42 & 31 & 22 & 39 & 1 & 8 & 11 & 23 & 17 & 14 & 13 & 11 & 2 & 1 & 0 & 87 \\
\hline Sweden & SE & 99 & 75 & 64 & 50 & 54 & 51 & 9 & 18 & 49 & 49 & 39 & 57 & 16 & 12 & 14 & 1 & 0 & 85 \\
\hline UK & UK & 91 & 76 & 51 & 37 & 40 & 50 & 64 & 38 & 31 & 30 & 19 & 9 & 10 & 14 & 10 & 7 & 2 & 83 \\
\hline Cyprus & $\mathrm{CY}$ & 85 & 46 & 34 & 40 & 33 & 8 & 28 & 12 & 2 & 13 & 19 & 0 & 17 & 18 & 2 & 14 & 1 & 71 \\
\hline Czech Rep. & $C Z$ & 85 & 73 & 14 & 14 & 36 & 16 & 0 & 20 & 30 & 5 & 3 & 3 & 6 & 9 & 1 & 14 & 1 & 79 \\
\hline Estonia & EE & 86 & 74 & 20 & 15 & 16 & 25 & 1 & 4 & 31 & 4 & 4 & 1 & 3 & 8 & 0 & 11 & 3 & 78 \\
\hline Hungary & $\mathrm{HU}$ & 66 & 49 & 10 & 9 & 24 & 12 & 1 & 12 & 20 & 3 & 1 & 1 & 6 & 3 & 1 & 33 & 1 & 54 \\
\hline Latvia & LV & 64 & 29 & 29 & 7 & 10 & 26 & 2 & 10 & 11 & 5 & 2 & 0 & 3 & 9 & 1 & 35 & 1 & 32 \\
\hline Lithuania & LT & 70 & 42 & 14 & 9 & 9 & 30 & 1 & 1 & 15 & 0 & 2 & 1 & 1 & 5 & 0 & 25 & 5 & 47 \\
\hline Malta & MT & 90 & 53 & 30 & 46 & 26 & 69 & 32 & 6 & 7 & 9 & 13 & 6 & 5 & 3 & 9 & 9 & 1 & 75 \\
\hline Poland & PL & 66 & 46 & 14 & 8 & 26 & 5 & 3 & 12 & 9 & 2 & 2 & 2 & 3 & 6 & 2 & 32 & 2 & 49 \\
\hline Slovakia & SK & 83 & 62 & 13 & 20 & 37 & 7 & 2 & 8 & 18 & 4 & 3 & 3 & 5 & 7 & 2 & 17 & 0 & 74 \\
\hline Slovenia & $\mathrm{SI}$ & 97 & 87 & 35 & 8 & 37 & 56 & 9 & 40 & 8 & 1 & 24 & 8 & 6 & 10 & 2 & 3 & 0 & 90 \\
\hline \multicolumn{3}{|c|}{ Predicted @ 50\% access } & 50 & 21 & 18 & 22 & 22 & 10 & 11 & 14 & 6 & 5 & 2 & 5 & 7 & 2 & & & \\
\hline \multicolumn{3}{|c|}{ Predicted @ 100\% access } & 78 & 44 & 40 & 49 & 38 & 24 & 20 & 23 & 25 & 18 & 15 & 11 & 10 & 7 & & & \\
\hline
\end{tabular}

Note: 'Access' means reporting at least one product. Source: Eurobarometer 230 (and special tabulation), European Commission (2005); and author's calculations. 
Figure 2: Use and portfolio share of risky assets in total financial assets by financial wealth and age, selected economies, 1990s

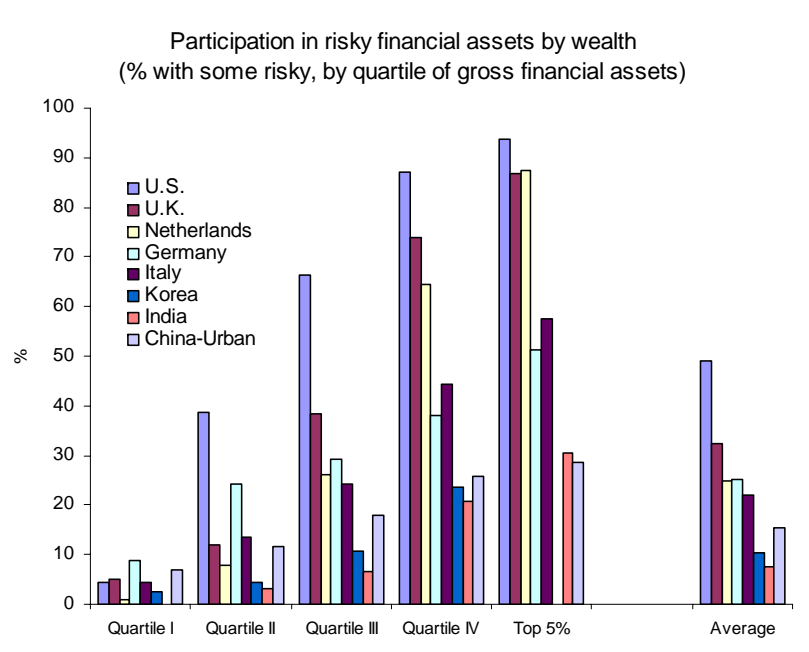

Share of risky assets in gross financial wealth by wealth quartile (conditional on some holdings)

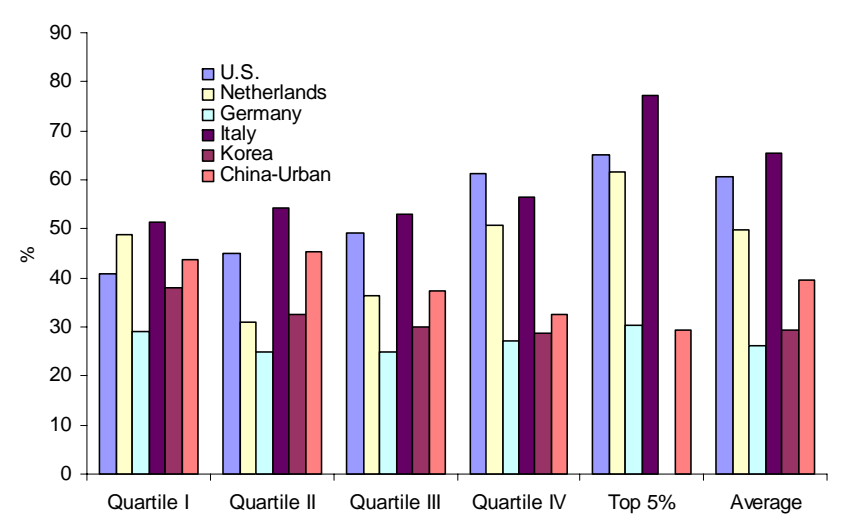

Participation in risky financial assets by age (share of each age group with some risky financial assets)
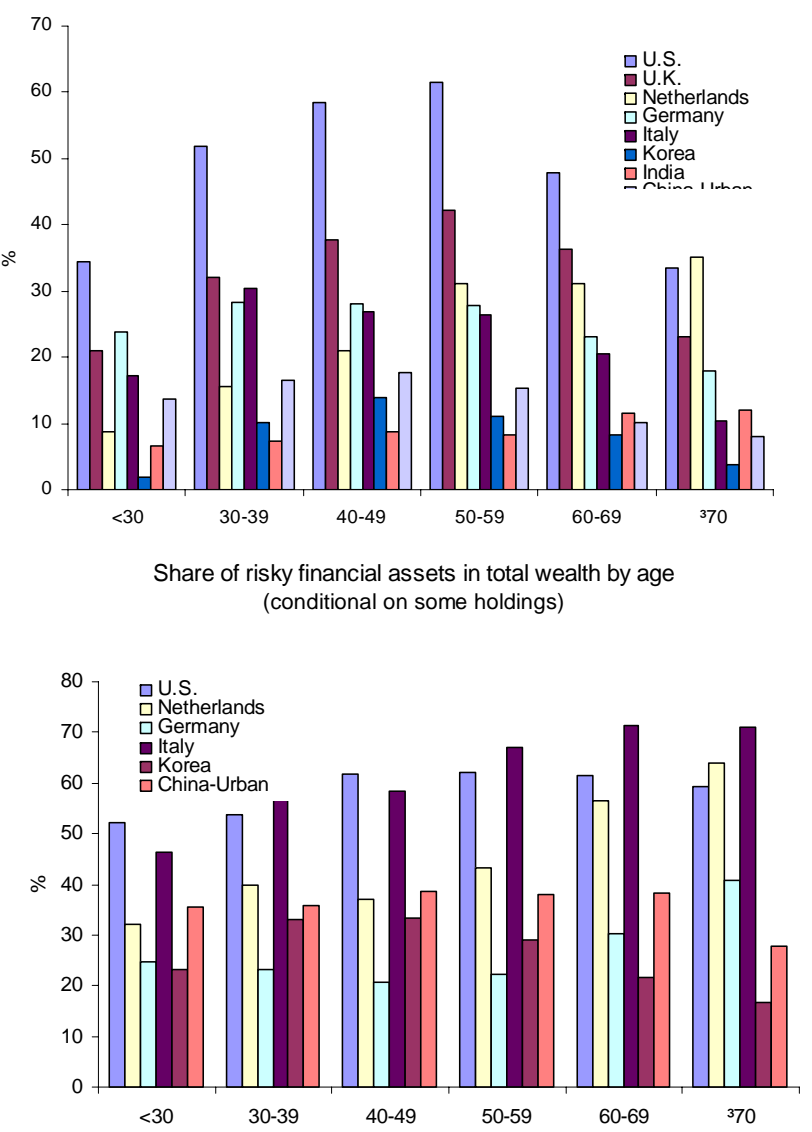

Source: Based on data in Guiso et al. (2002); Kar et al. (2001); for China, special tabulations by Ding Sai based on CASS 2002 survey (Li and Zhao 2006); for Korea special tabulations by JaeChil Kim of KSRI based on the Korea Household Income and Expenditure Survey of the National Statistics Bureau. Note for India and Korea the quartiles are income, not wealth. 
Figure 3a: Ghana: use and distribution of savings balances

Ghana: Financial assets by consumption percentile

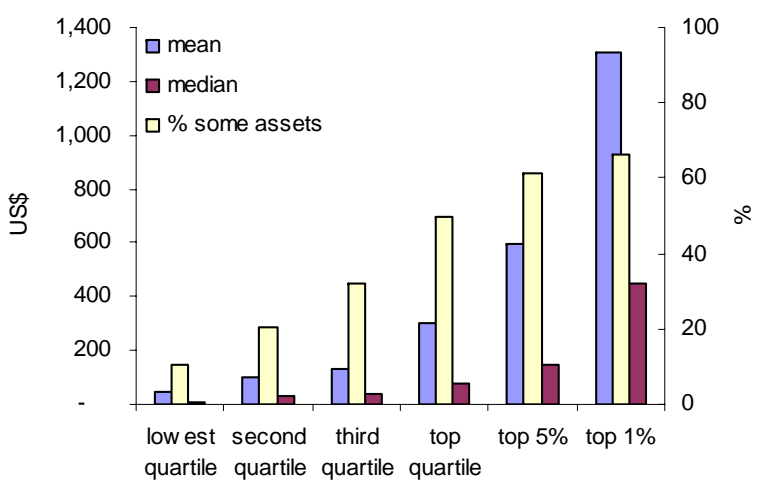

Ghana: Financial assets by education

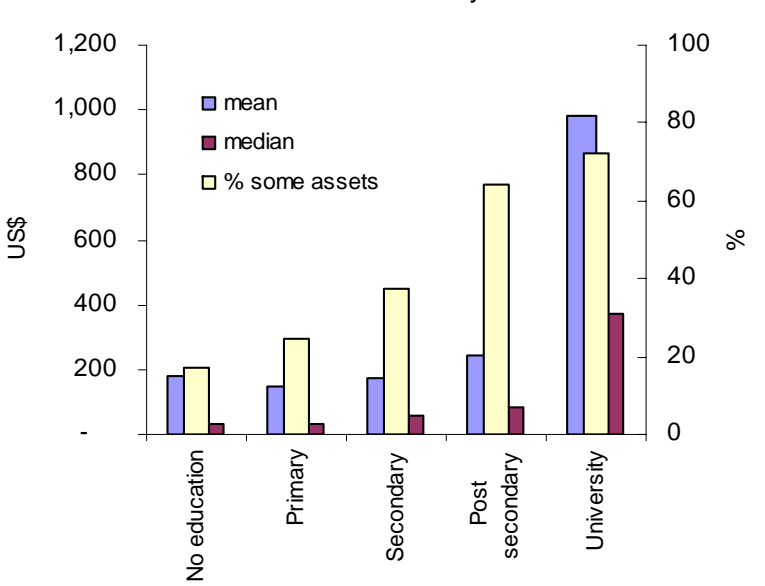

Ghana: Distribution of financial assets (savings balances; by quartile of consumption)

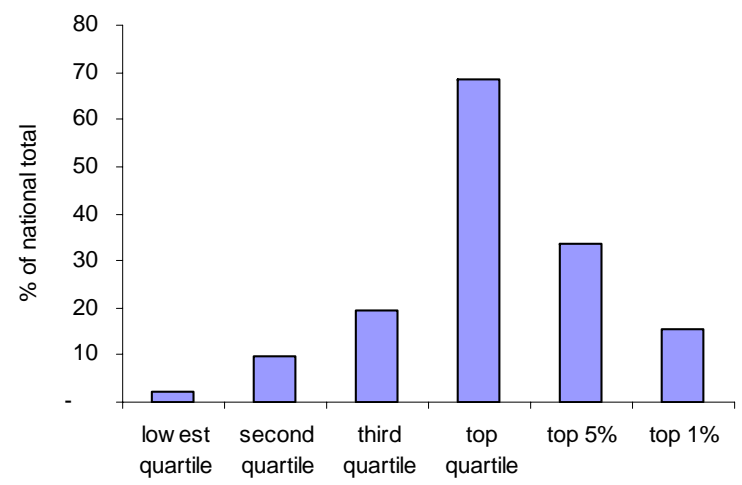

Ghana: Financial assets by age

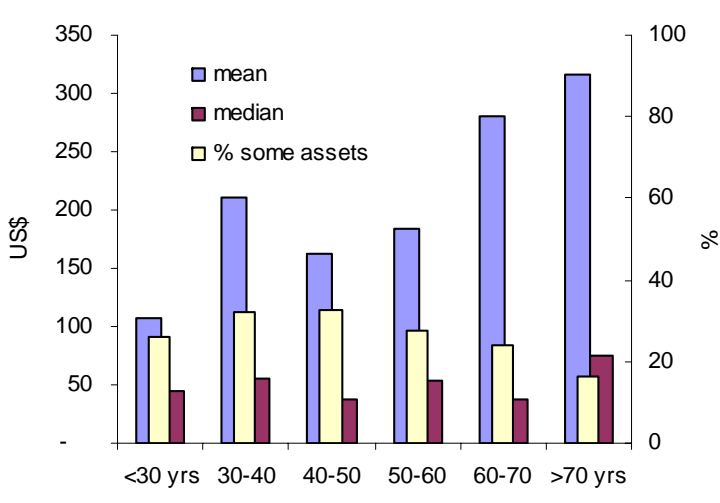

Source: Author's tabulations based on Ghana LSMS 1999 
Figure 3b: Vietnam: use and distribution of savings balances (conditional on reporting a holding)

Vietnam: Financial assets by consumption percentile

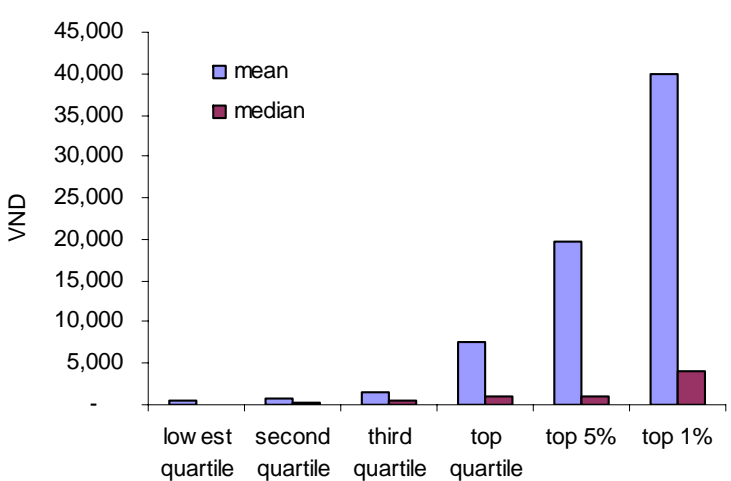

Vietnam: Financial assets by education

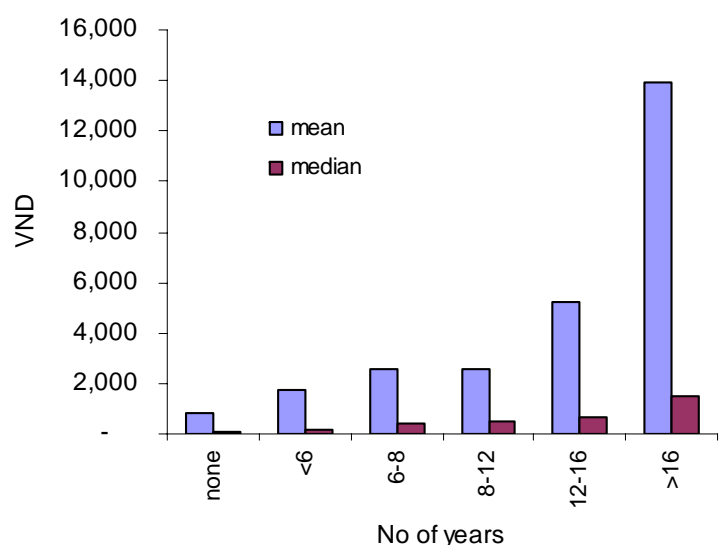

Vietnam: Distribution of financial assets (by quartile of consumption)

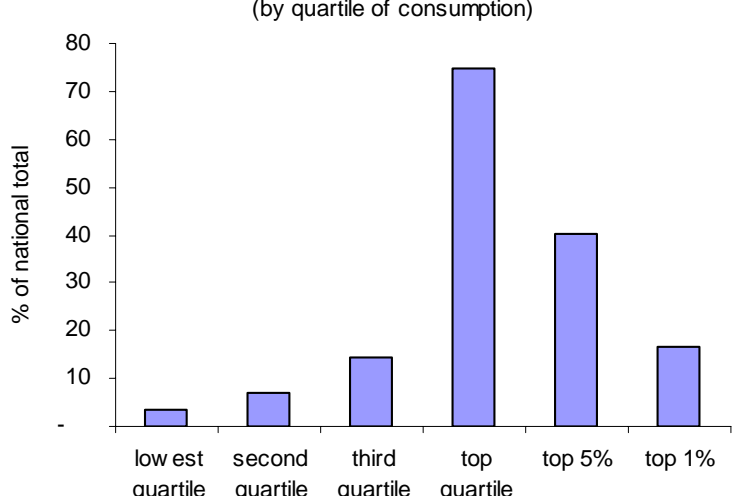

Vietnam: Financial assets by age

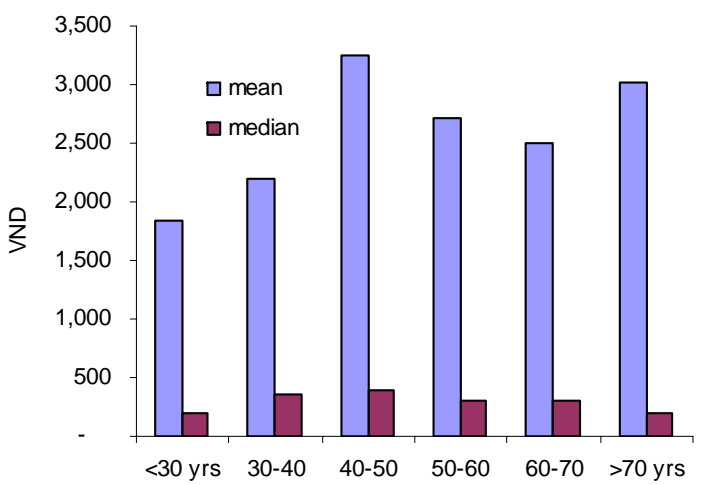

Source: Author's tabulations based on Vietnam Living Standards Survey (VLSS), 1997-98. 
Figure 3c: Jamaica: use and distribution of reported savings balances

Jamaica: Financial assets by consumption percentile

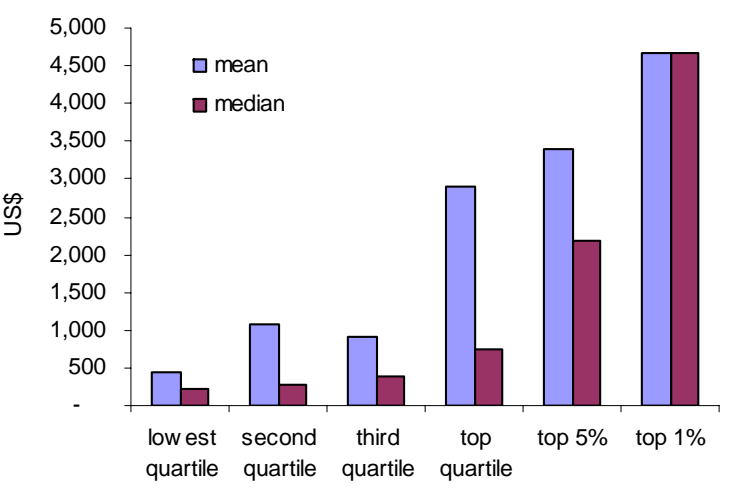

quartile quartile quartile quartile

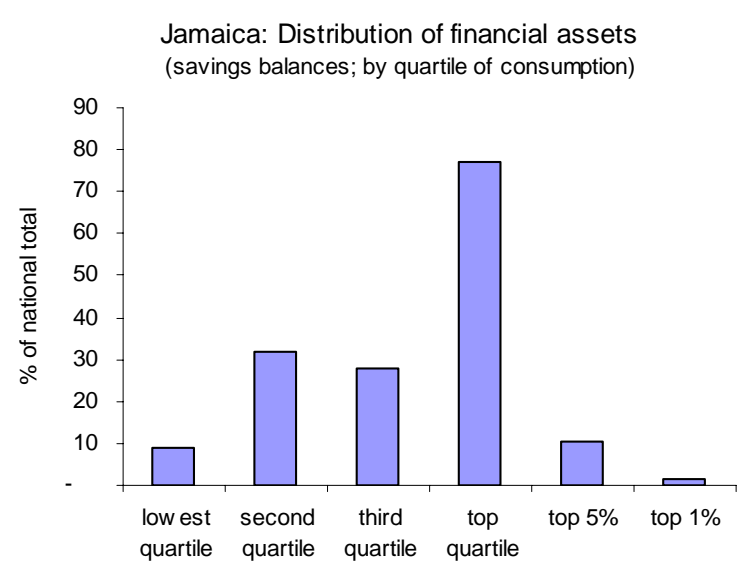

Jamaica: Financial assets by age

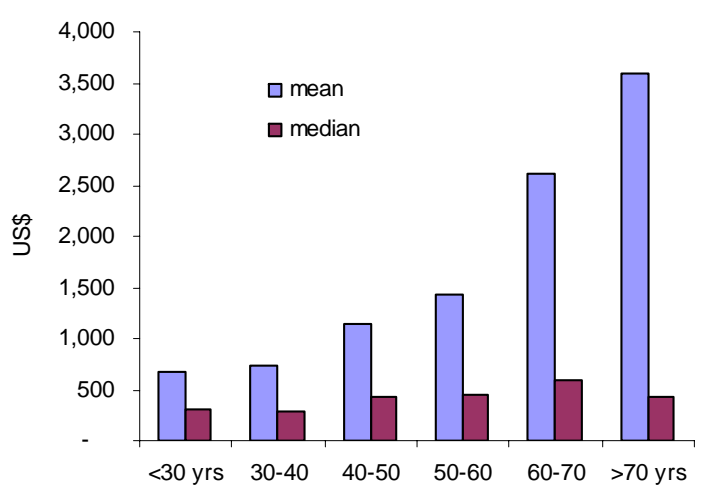

Source: Author's tabulations based on Jamaica Survey of Living Conditions 2004. 
Figure 4a: Strong correlation between credit and deposit measures of financial depth: private credit and liquid liabilities expressed as a multiple of GDP

Financial depth measures:

Liquid liabilities and private credit, 2003

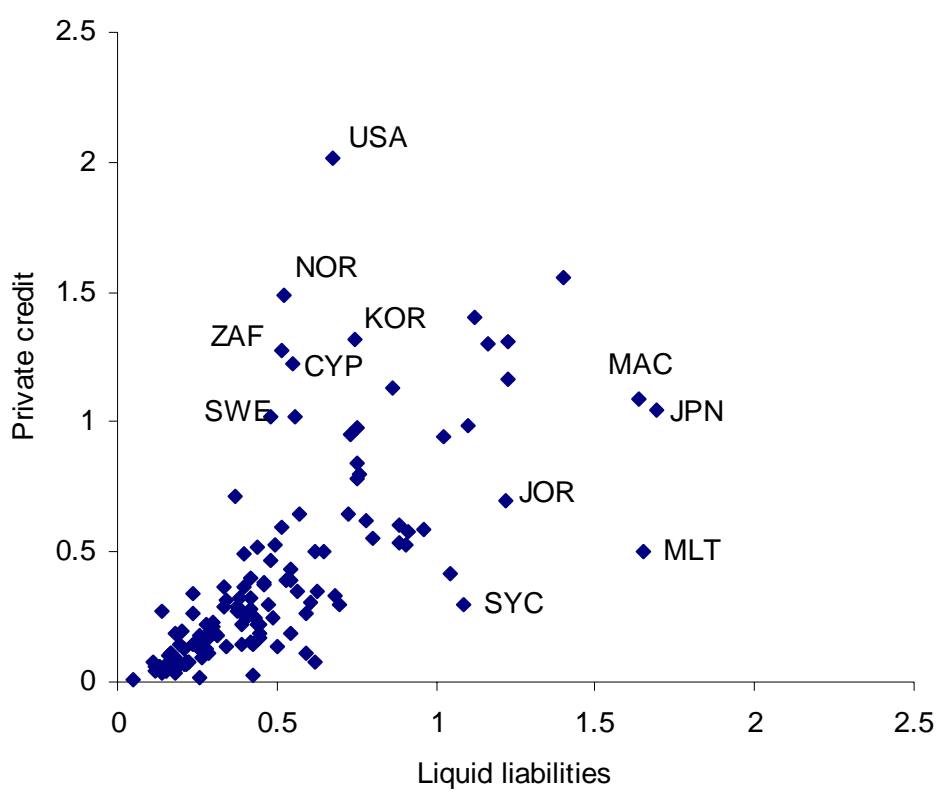

Source: World Bank Financial Structure Database.

Figure 4b: Financial Structure and Per Capita Income, Developing Countries 2003: Ratio of stock market capitalization to liquid liabilities of the banking system plotted against per capita GNI

Financial structure and per capita income

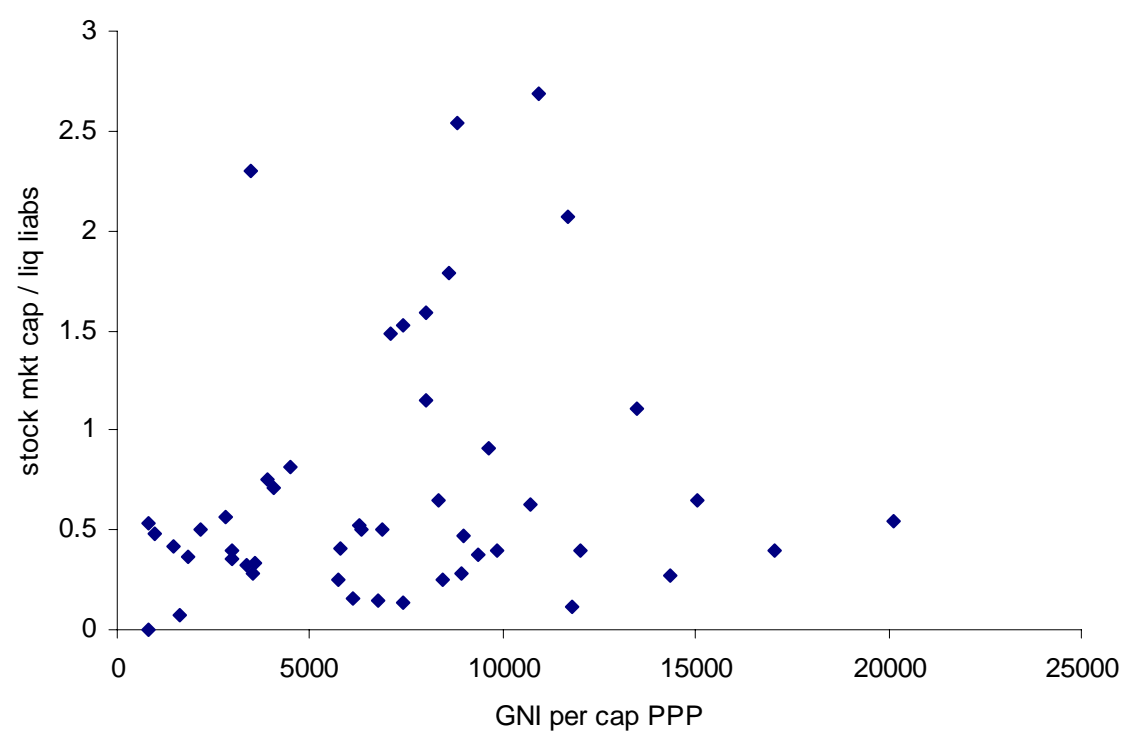

Source: World Bank Financial Structure Database. 
Figure 5: Access to finance by country, regional extremes, medians and means (composite series)

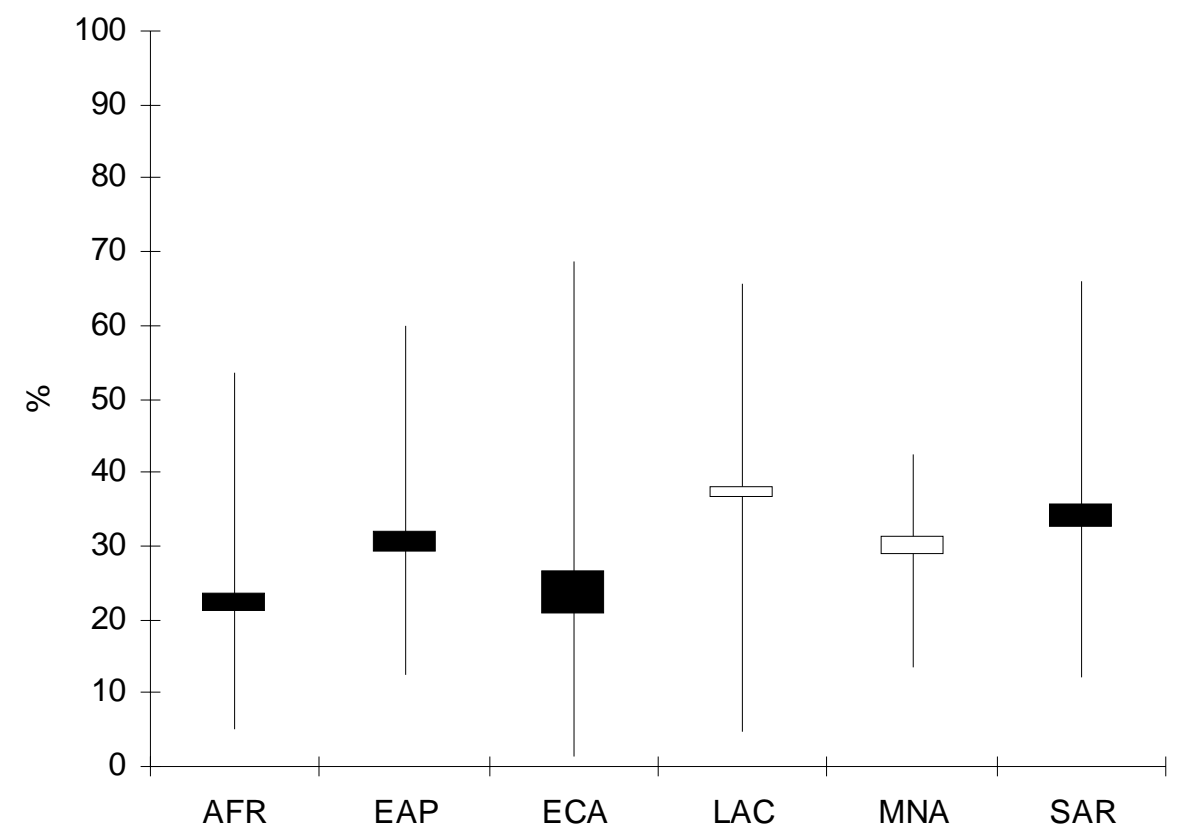

Note: Percentage of adult population with access to an account. Shows mean, median, max and min values for countries in each region. The median is higher than the mean LAC and MNA, mean is higher than median elsewhere. ECA excludes EU member states.

Source: As for Figure A1.

Figure 6: Access and per capita income, 160 countries

\section{Access and GNI per capita}

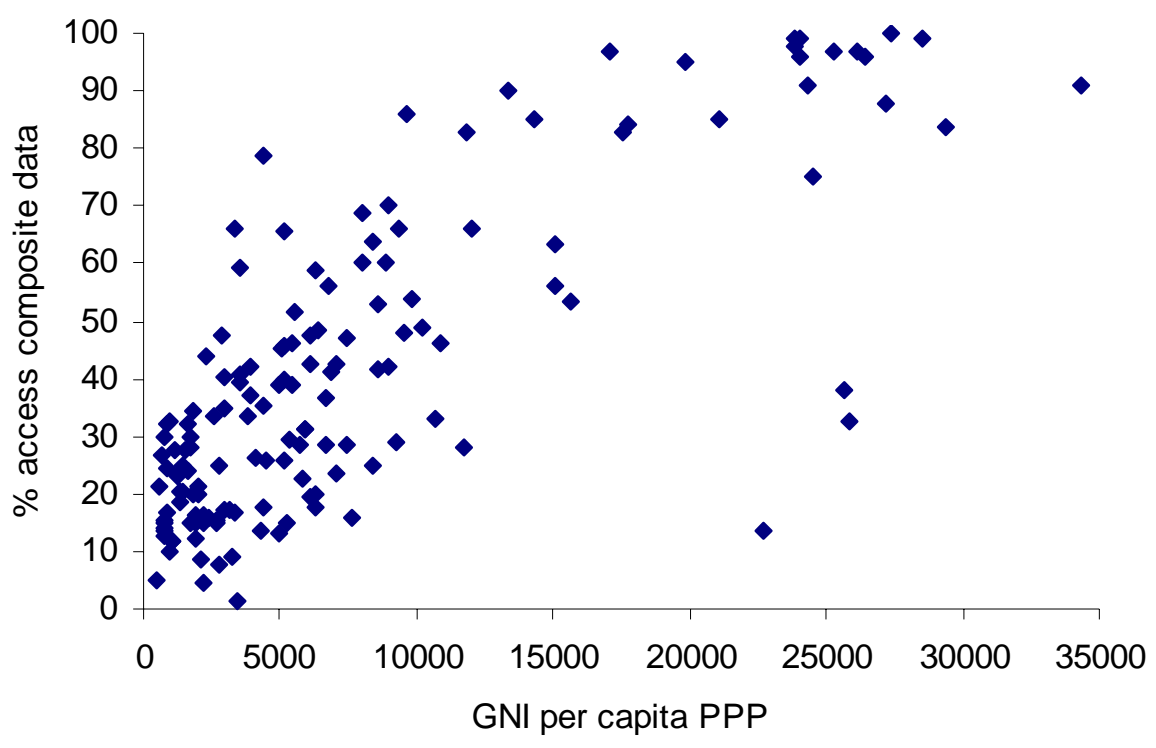

Note: This uses the composite access indicator-for definition see Appendix 2. GNI per capita data from WDI. The three outliers on the lower right hand side are Hong Kong, China; Macao, China; and United Arab Emirates. 
Figure 7: Access to finance and per capita GDP, 25 EU countries

\section{EU25 Access and Income}

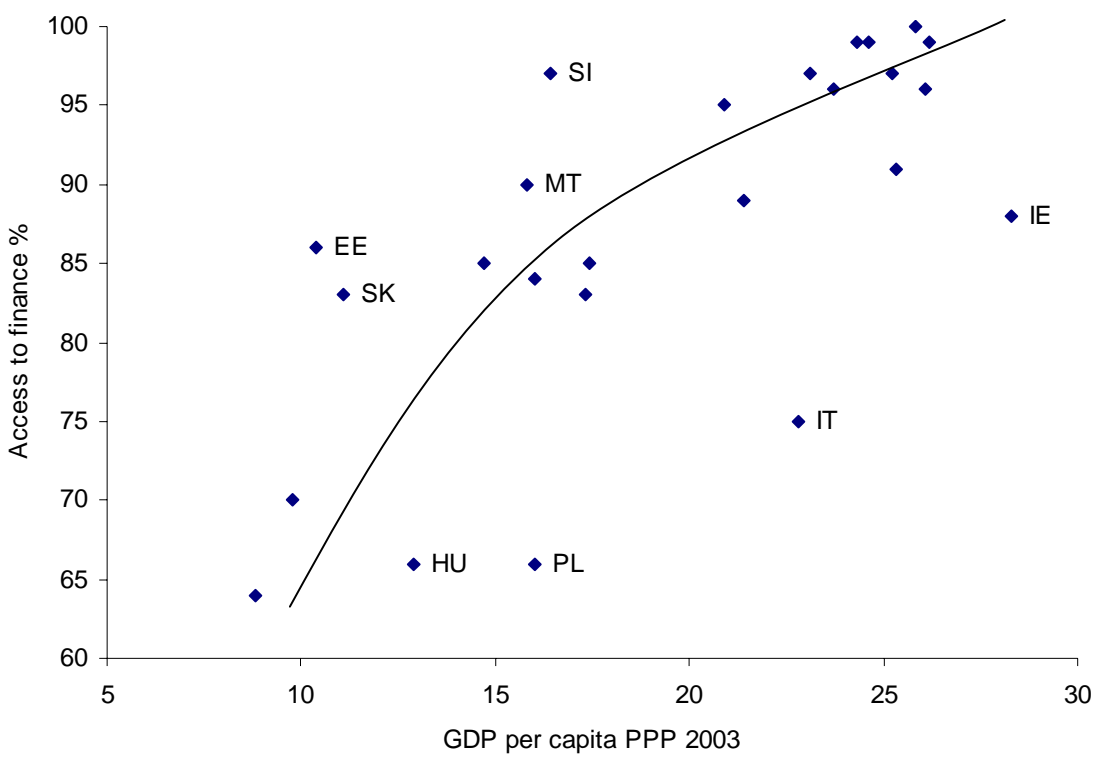

Source: Access based on Eurobarometer 230 (European Commission 2005). Access percentages are 100 less the percentage reporting none of 14 listed financial products, less the percentage reporting 'don't know'. GDP per capita measured in thousands of Euro, source Eurostat.

Figure 8: The order in which different financial products are acquired

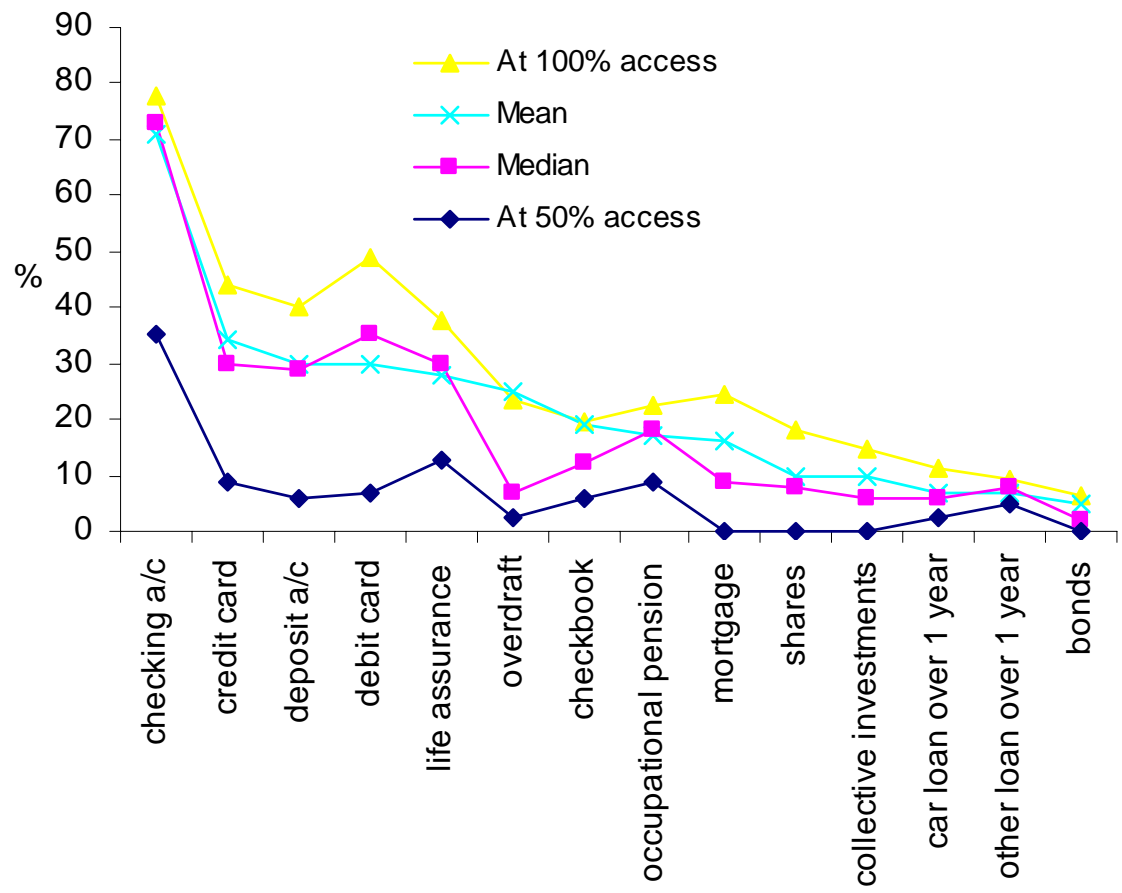

Note: The figure shows the median and mean usage percentages across EU member states of the different products listed in Table 3, together with the fitted percentages from the regression reported in Table 4 for 50 per cent and 100 per cent basic access. 
Various explanations have been advanced for deviations from household portfolio efficiency, including inadequate financial education,27 weak investor protection 28 and lack of trust (Guiso et al. 2005). 29 These issues have been little considered in the developing country context, and the limited data on age and education patterns are only moderately informative here. In practice, the use of non-cash financial assets is highly correlated with education levels in China, Ghana and Vietnam (but education in turn is correlated with income). 30 In addition to advocating a more adventurous portfolio, financial planners often recommend that the riskiness of the household portfolio should decline as households near retirement- $\mathrm{a}$ form of turnpike theorem for investment planning. Looking therefore at variations in the share of risky assets with age, no strong pattern emerges consistently across countries for which data is available. There is a hump-shaped pattern — as would be recommended by financial planners-for the US, the UK and Germany (Figure 2), but a trend increase for the Netherlands and (at least as far as participation is concerned) for India. The reduced share of risky assets held by older people in the US is less than would be recommended by financial planners (Ameriks and Zeldes 2004). 31 There is no pronounced age-risk correlation for any of the developing countries for which we have data. Given that different age groups also represent different cohorts in these data, however, there is an identification problem in separating the effects of calendar time and age.

Supply conditions can also strongly affect household portfolio composition in developing countries including the choice between risky and safe assets, especially, but not only, when exchange controls limit international diversification. Legal, regulatory and tax policies can strongly affect the cost and availability to lower income households of such products as insurance and mortgage finance. Equity is the prime risk product, and availability of traded equity has been greatly increased in many developing countries through privatization. This process has been enormously influential in increasing participation in equity markets (Boutchkova and Megginson 2000), even though the voucher-based experiments towards popular capitalism in Eastern Europe were quite problematical (Ellerman 2001). In turn the political commitment, which

27 Lusardi and Mitchell (2006) found astonishing levels of financial ignorance when they added a module on financial education to a 2004 US survey on health and retirement issues.

28 Giannetti and Koskinen (2004) present data for 26, mostly advanced, economies on the percentage of households holding equities; they find a positive correlation between these percentages and measures of investor protection.

29 Rosen and Wu (2004) show that households with poor health status hold less risky assets.

30 See Figure 3 for Ghana and Vietnam. For urban households in China, the share holding risky assets increases monotonically with education categories from $0.1 \%$ of those with below primary level to over $10 \%$ for those with post-graduate qualifications (CASS survey special tabulations).

31 However, as Ameriks and Zeldes show (2004), the apparent downward trend with old age is not confirmed by a more thorough multivariate microeconometric analysis of the US data-an observation which should act as a caveat for conclusions based on the simpler univariate approach adopted here. 
privatization to domestic households can represent, lowers political risk and increases stock market valuations which in turn can favourably affect growth (Oijen and Perotti 2001). Moving beyond the risky/safe dichotomy, available data is not only limited but hard to bring to a common base, given the different types of financial asset and financial product and the different ways in which information about holdings has been measured in different countries. One large cross-country database that avoids these difficulties is that assembled in recent years for the 25 member states of the EU (EU), which now includes some middle-income countries. 32

Table 4: Analysis of product semi-elasticities with respect to overall access

\begin{tabular}{lrrrr}
\hline & constant & access & t-stat & RSQ \\
\hline Checking a/c & 0.78 & 0.96 & 3.9 & 0.40 \\
Credit card & 0.44 & 0.79 & 4.4 & 0.46 \\
Deposit a/c & 0.40 & 0.77 & 3.4 & 0.33 \\
Debit card & 0.49 & 0.94 & 3.8 & 0.39 \\
Life assurance & 0.38 & 0.57 & 4.2 & 0.43 \\
Overdraft & 0.24 & 0.48 & 2.6 & 0.23 \\
Checkbook & 0.20 & 0.30 & 1.1 & 0.05 \\
Occupational pension & 0.23 & 0.32 & 1.9 & 0.13 \\
Mortgage & 0.25 & 0.64 & 3.8 & 0.38 \\
Shares & 0.18 & 0.47 & 4.3 & 0.45 \\
Collective investments & 0.15 & 0.43 & 2.9 & 0.27 \\
Car loan over 1 year & 0.11 & 0.20 & 2.7 & 0.24 \\
Other loan over 1 year & 0.10 & 0.10 & 1.6 & 0.10 \\
Bonds & 0.07 & 0.16 & 2.6 & 0.23 \\
\hline
\end{tabular}

Note: The table shows the estimated intercept and coefficient on log(access) in a regression of the percentages using each product across the EU25.

Source: Author's calculations based on the data in Table 3.

The pattern of usage of different financial products found in the EU data (Table 3) suggests a fairly clear pecking order for some products, in that there is a fairly regular progression in the use of these products as overall financial access increases. (Here overall financial access is measured by the percentage of respondents who report use any of the products). By regressing for each product the percentage using that product

32 The European Commission have conducted financial surveys in member states almost every year since the late 1990s. The objective of the survey includes analysis of satisfaction with products, confidence in intermediaries and the effectiveness of cross-border competition. The data discussed here were collected in 2005 and reported in European Commission (2005). Thanks to Francesco Gaetano for the special tabulation in the final column of Table 3 showing usage of either checking or deposit account; also plotted in Figure 7. The European Commission stresses however, that the Eurobarometer survey was designed to elicit attitudes about the importance of various financial issues rather than measuring usage, therefore the statistics on usage should therefore be treated with caution. In particular, they caution that 'the given response rate should not be misinterpreted as implying that the remaining proportion of respondents do not have the corresponding item'. 
on (the log of) overall financial access, we can estimate how sensitive each product is to overall usage. The results are summarized in Table 4 and Figure 8. The intercept represents the estimated usage for a country where there is 100 per cent access. 33 At that point, checking account usage is projected at 78 per cent, 34 and holdings of bonds at 7 per cent. Projected usage at 50 per cent access is also shown in Table 4. Checking and deposit accounts and their associated cards are in the first rank for usage. Life assurance comes next, followed at some distance by the various loans and more complex investment instruments. Check-book, overdraft and occupational pensions have much higher variance of usage, little of which can be explained by variations in overall access: instead these should be seen as system-specific rather than generic products.

\section{Concluding remarks}

Financial asset holdings by households are highly concentrated; in the US one-half of households own about 97 per cent of financial assets. The savings they represent are pooled and transformed by financial intermediaries and markets, enhancing their risk and return. Although firms are also providers of funds to intermediaries and markets, the savings of prosperous households ultimately represent a large fraction of the resources employed by the financial sector in its provision of risk-reduction services and investable funds. As such, they are a key ingredient in the growth-promoting process of financial intermediation.

Data on the financial asset holdings of households in developing countries are very sparse indeed. The quality of data for the handful of countries for which systematic surveys have been conducted is suspect, with indications that asset holdings of the highest income groups are systematically understated. For low-income countries, the relevant question for poor households is not how much financial assets they have, but whether they have access to financial intermediaries at all. We have drawn on and synthesized recent work by several authors using information provided by banks and microfinance institutions in combination with household survey data to produce estimates of access percentages for almost 150 countries. These estimates can be progressively refined as the results of a new wave of access surveys currently under way or planned become available.

\footnotetext{
33 When a country reaches 100 per cent access, usage of products may continue to grow-attempts to deal with this by adding a term in per capita GDP does not prove to yield precisely estimated coefficients on this rather small dataset.

34 Checking accounts and deposit accounts appear to be substitutes in the sense that inclusion of the percentage using deposit accounts results in a much improved fit; the estimated coefficient on deposit account usage is -0.52 . No other substitutes were found in the data.
} 
The new access percentages are negatively correlated across countries with poverty rates, but the correlation is not a robust one and loses significance in multiple regressions that include mean per capita income. Thus the supposed anti-poverty potential of financial access remains econometrically elusive. Data for developing countries is insufficiently rich to assess whether asset choice by households is consistent with rational choice, a question on which there has been much discussion for advanced economies. Once again, it is more a question of whether households actually use any of a range of different types of financial instruments, than of whether they have chosen the optimal quantities of each in their portfolio. Analysis of data from the EU-25 suggests a ranking of different financial instruments and products in terms of the level of income at which each will be widely used-checking and deposit accounts and their associated cards come first, followed by life assurance and then loans. 


\section{Appendix 1: A few definitions}

As the paper concentrates exclusively on financial assets, it is desirable to clarify what is included and what excluded by this convention.

Financial assets represent contractual claims on other agents and are as such differentiated from other physical or tangible assets such as land, buildings and machinery. While the value of a financial asset may be considered to derive from the wealth of the issuer, attempts to trace the value of a financial asset through a sequence of such claims to an underlying nonfinancial asset are in practice blurred and dissolved by the pooling of claims through intermediaries and by the contingent nature of such derived claims.

Financial assets include cash (notes and coin), deposits at banks and other intermediaries, tradable equities, government and corporate bonds, and holdings of managed funds. A wide range of variants and derivatives of these basic financial assets are also included, and these have become increasingly important in advanced economies. The three main areas of ambiguity in drawing the line between financial and non-financial assets are in the area of insurance, pensions and equities.

For statistical purposes, the only insurance claims that are customarily measured as financial assets are life assurance policies, and they are included only to the extent of their surrender (cash) value. This may substantially under-represent the discounted present value of the expected benefits from the policy.

As to pension and retirement fund claims, the market value of defined contribution funds are generally treated as a financial asset, but the value of occupational defined benefit funds and any expectation of social security or social assistance pensions typically is not, at least partly because of difficulties of measurement.

For equities, only those that are freely tradable (and thus excluding ownership claims on enterprises that have not adopted the procedures for public tradability of their equities) are included as financial assets. The idea here is that a share in a privately-owned company is quite close to direct ownership of part of the company's assets and as such ought to be excluded. A difficulty here is that many listed companies are controlled by a small group of shareholders - perhaps a family — either through a majority stake, or a sufficiently large minority stake, perhaps involving a pyramidal structure of ownership. While these insider stakes will normally be treated as financial assets, given that identical holdings by non-controlling shareholders are clearly financial assets, the degree of control over the assets of the company which they represent is close to being non-financial in nature. Of these three frontier categories, pension and equity holdings are among the most rapidly evolving asset classes, and have been the subject of farreaching policy initiatives in many countries related in particular to changing longevity and privatization of public enterprises. 


\section{Appendix 2: A new composite series on household access to financial services}

This Appendix discusses some recent contributions to measuring access of households to various forms of intermediary accounts, and proposed a new composite cross-country indicator of the percentage of the adult population with access to some intermediary account. The new series has the advantage of wide coverage-almost 140 countriesand the drawback of relying for many countries on some rather shaky imputations.

In recent contributions, two basic approaches have been used to get to grips with the problem of measuring overall financial access (Honohan 2005). One is to go directly to households and survey their usage, whether as part of a wider household survey or a dedicated financial access survey. The other is to make inferences from data in the number of intermediary accounts. The annex proposes a method of using overlaps between the country coverage of the different approaches to arrive at access estimates for 162 countries-or almost three times the number of countries for which there is direct household survey data.

The first method of measuring access, namely the use of sample surveys of households or individuals, is the most satisfactory from a conceptual point of view. The surveys that have produced data here include general household surveys such as the LSMS series (which can include a savings module asking questions about the holding of savings) and specialized financial access surveys, such as the Finscope series which began in Southern Africa and are currently being rolled out in several other African countries. The series of Eurobarometer surveys in the EU also ask such questions (cf. European Commission, 2005). Unfortunately the number of countries covered by household survey data remains modest, and there are indications of problems with the reliability some of the data collected. 35

The second method is to collect data on the number of accounts maintained at the financial institutions. This has been done in respect of microfinance in 148 developing countries by Christen et al. (2004) of CGAP, building on earlier compilations for more limited groupings. They include not only specialized microfinance institutions, savings and credit cooperatives, credit unions and other socially-oriented intermediaries (including some microfinance-oriented commercial banks) and they term these 'alternative' intermediaries.36 More recently, Peachey and Roe (2006) have augmented the CGAP database with figures for a number of additional savings banks (members of the World Savings Banks Institute), which had not been included by Christen et al. We

35 The Eurobarometer surveys have been repeated on a roughly annual frequency with some startling year-to-year jumps in the responses, despite only small change in the questions answered.

36 Christen et al. (2004) define their coverage as including intermediaries that have a 'double bottomline', reflecting social (access to finance) as well as strictly commercial objectives. They include government-owned development banks and savings banks. 
describe this augmented set as the 'WSBI database'. The additions are important. Many of the institutions added by Peachey and Roe, most of them postal savings banks, have very wide outreach by national standards: in 27 countries they represent more than 50 per cent of the number of accounts recorded. Furthermore, the additional banks include two very large ones (the Industrial and Commercial Bank, ICBC, of China and Sberbank, Russia, with 0.43 and 0.23 billion accounts respectively); their inclusion accounts for the fact that the augmented dataset contains more than twice as many accounts-1.46 billion instead of 0.67 billion-thereby sharply revising aggregate access estimates.

Figure A1 presents the distribution across countries of number of microfinance accounts per 100 adult population using the WSBI series. It also shows the same for microfinance accounts that are not savings bank accounts (based on the CGAP numbers). It suggests a rather better access picture than indicated in earlier work, and in particular shows that ignoring the large government-sponsored savings banks leads to a considerable understatement of the number of bank accounts (though it should be noted that many of these savings banks do not offer credit services to individual customers).

A parallel exercise for banks was conducted mainly through a survey of banking regulators (Beck et al. 2005). Data on the number of deposits at 1999-2000 was obtained for 45 countries-35 of them developing countries. However, this survey covers only those institutions regarded as 'deposit money banks' and as such does not cover most microfinance institutions.

A number of difficulties arises in moving from these two databases to a reliable indicator of the proportion of households with financial access. For one thing, there is unfortunately an overlap between the coverage of the two databases on numbers of accounts, as some commercial banks are included in the WSBI sample, and elimination of this overlap has not yet proved feasible. Then again there is the problem of inferring the number of distinct and active accountholders from data on numbers of accounts, as many individuals have multiple accounts. On the other hand, some accounts are recorded even though they have long been inactive. There is sure to be a large variation from country to country and between different types of banks in the degree to which these problems result in the aggregate number of accounts exceeding the number of individuals with accounts. The typical individual in more advanced financial systems likely holds a greater number of accounts than in less advanced economies. And there are widely differing practices with regard to multiple accounts. For example, the ICBC - with the largest number of individual accounts of any bank, is currently carrying out a campaign to consolidate multiple accounts. 37

37 Interestingly, the bank's notice to customers dated October 18, 2005, urging them to close or merge accounts containing small balances, identifies no fewer than 11 classes of account which should not be closed. 
There are other loose ends. For instance, while the accounts at ICBC are included in the WSBI data, the 146 million active personal deposit accounts at another large Chinese institution, the China Commercial Bank are not, essentially because it is not a member of the WSBI. Both of these banks would be included in the concept of 'commercial banks’ employed by Beck et al. (2005) for their survey, though data for China has not been included in that survey. 38

Figure A1: Access to finance, estimated deciles of country data

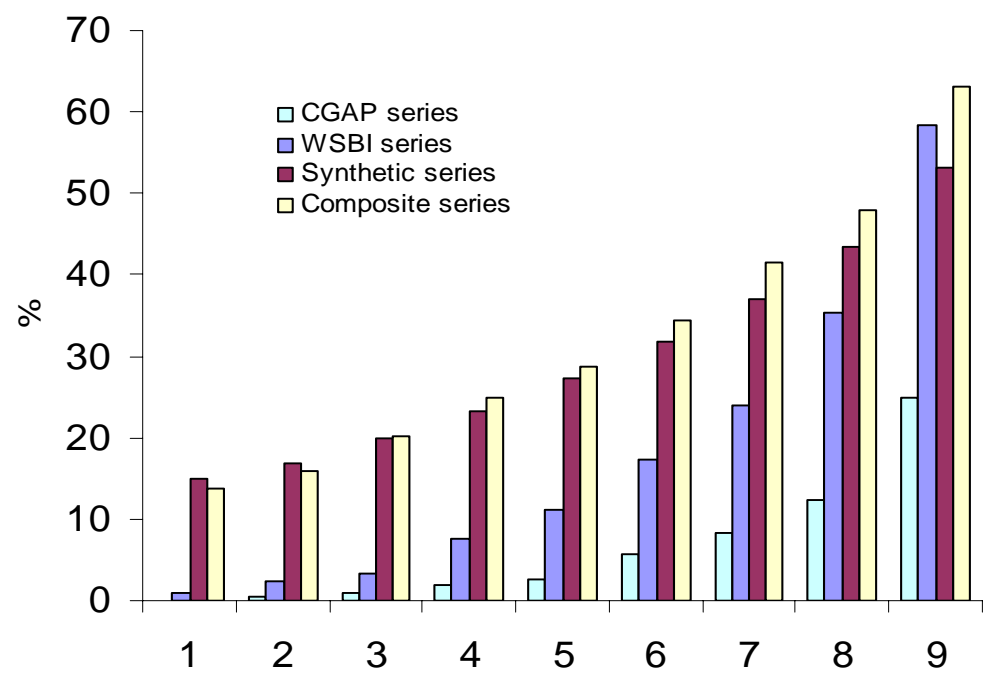

Note: The four series shown are: (i) based on the CGAP data for 'alternative' financial intermediaries; (ii) based on the expanded WSBI data including additional savings banks; (iii) the Synthetic series based on regression $\mathrm{J}$ in Table 1; (iv) the Composite series which substitutes actual household survey data for the synthetic series where available. Example: 70 per cent of 138 developing countries in the database have at least 41.2 accounts per 100 adult population according to the Composite series.

Source: Author's calculations based on Regression J table A1; underlying data drawn from: Beck et al. (2005); Christen et al. (2004); Claessens (2005), European Commission (2005) (Household Survey); Peachey and Roe (2006).

Given these numerous difficulties it is heartening to discover that data on bank account numbers and on average bank account size (as a proportion of GDP) are quite closely correlated with household survey-based data on access percentages (Table A1, regressions $\mathrm{A}$ and $\mathrm{B}$; and Figure $\mathrm{A} 1$ ). The log-linear relationship is close enough to suggest using extrapolating fitted values for countries in which there is no household survey data available. Using the bank account database, this allows synthetic access percentages to be derived for about 45 countries. Even more encouraging, for countries where both exist, the bank account numbers are quite highly correlated with-though not equal to- - the WSBI numbers (Table A1, regression L). Thus, where the number of

38 The household survey percentages used here are drawn from the compilation in Claessens (2005), the original surveys were conducted with various methodologies and at various dates between 1988 and 2004. Including the date of the survey in the various regressions changes little. 
bank accounts is not known but the WSBI numbers are, we can use the fitted relationship to compute a substitute regressor. Using this substitute, we obtain $G$, which shows that the relation between accounts numbers and household survey data holds up well on a much wider sample. The coefficient values from $G$ can then be used to approximate access percentages for all 138 countries in the WSBI database. As a further refinement, noting also the correlation between the deposit size data and GDP per capita (regression $\mathrm{M}$ ) one can proceed in an analogous way using the fitted values from $\mathrm{M}$ as regressors in J, whose coefficient values in turn generates an alternative approximation to the access percentages. We call this alternative the synthetic access percentage.

Figure A2: Fit of the equations linking (a) actual and (b) synthetic bank accountsbased information with household survey-based access data

Actual and fitted access indicators

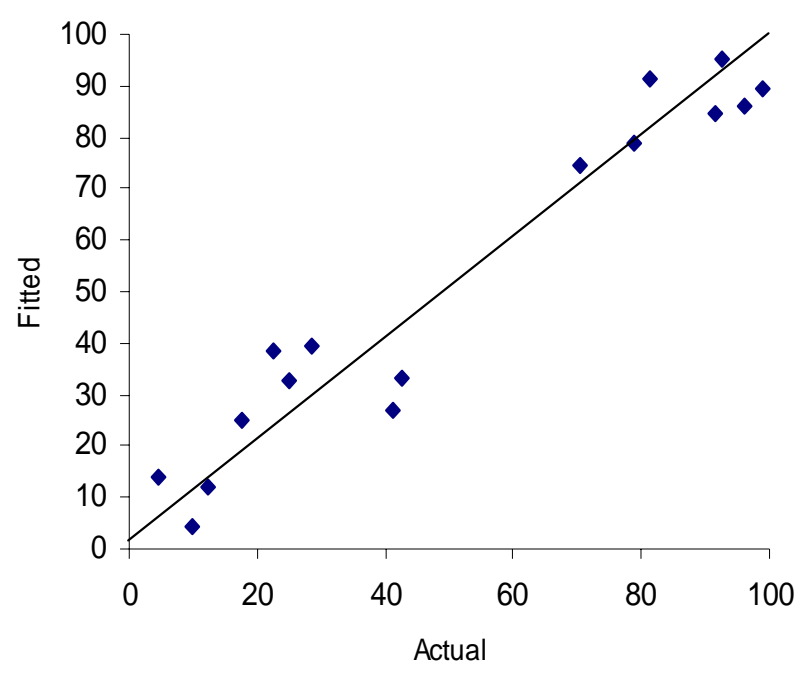

Actual and fitted access indicators

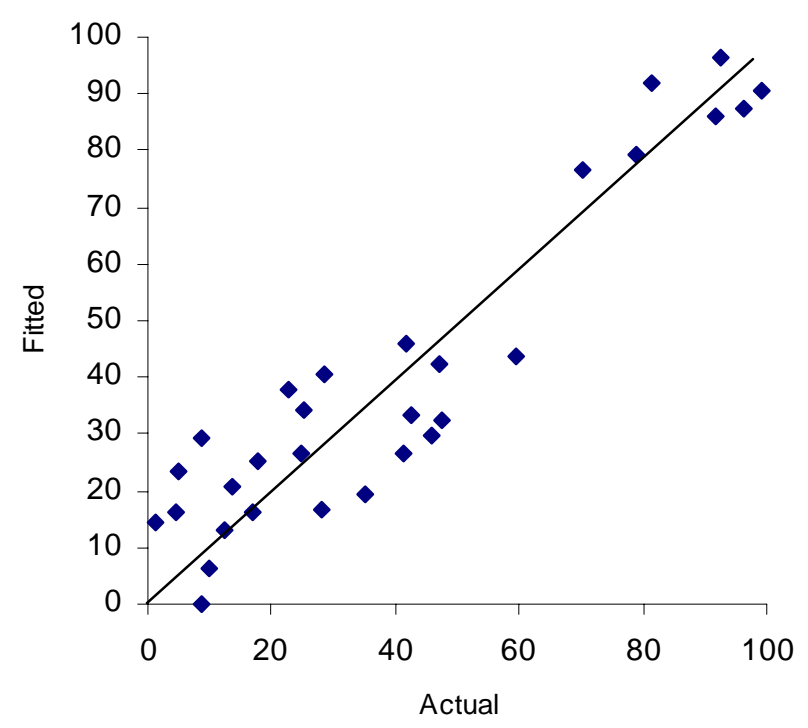

Note: based on Regressions $1 \mathrm{C}$ and $1 \mathrm{~J}$ in Table A1. 
In notation, let $m_{i}$ is the ratio of MF accounts and $b_{i}$ the ratio of bank accounts to adult population in country $i$; let $h_{i}$ be the household survey-based percentage access, $z_{i}$ the average deposit size and $y_{i}$ per capita GDP. Let $\hat{\alpha}_{k}$ be the fitted values in a log-linear regression of $b$ on a constant term and $m$, and $\hat{\beta}_{k}$ the fitted values in a regression of $z_{i}$ on a constant and $y$.

Then, let $\hat{b}_{i}=b_{i}$ for countries where data on $b_{i}$ is available, $\hat{b}_{i}=\hat{\alpha}_{0}+\hat{\alpha}_{1} \log \left(m_{i}\right)$ otherwise; $\hat{z}_{i}=z_{i}$ for countries where data on $z_{i}$ is available, and $\hat{z}_{i}=\hat{\beta}_{0}+\hat{\beta}_{1} y_{i}$ otherwise.

Let $\hat{\gamma}_{k}$ be the fitted coefficient values from a log-linear regression of $h$ on a constant, $\hat{b}$ and $\hat{z}$.

The synthetic access percentages are then obtained by computing $\hat{\gamma}_{0}+\hat{\gamma}_{1} \log \hat{b}+\hat{\gamma}_{2} \log \hat{z}$.

A final adjustment is to replace this last mentioned synthetic access data with surveybased data where available. The result 39 is the composite indicator tabulated in Table 1, and on which Figures A2, 5 and 6 are based.

Figure 5 also shows the deciles for the synthetic and composite access indicators. Note that the synthetic indicator is distributed more evenly than the basic WSBI accounts numbers, partly because of the use of a logarithmic transformation of account numbers, which is preferred by the data (as is indicated by regression F) and which is consistent with the plausible idea that, as deposit account numbers grow, access percentages do not grow proportionately. However, the spread of the actual distribution out of sample is likely to be also understated by the deciles shown, given that the fitted value has a much lower standard deviation than the actual within sample.

Despite the numerous shortcomings of the composite indicator, it has the great merit of distilling information from a variety of different sources and placing it on a common basis. No doubt the accuracy of the imputation for any given country may be highly questionable, but it can represent a first approximation to be revised as new data become available for each country. Furthermore, as a cross-country dataset, it has certainly potential for use in cross-country regression analysis, where econometric techniques can minimize the impact of stochastic errors.

39 In addition, a final adjustment was made to prefer the predictions from $B$ to those from J, where the former was larger; i.e., the WSBI data was not allowed to result in a lower composite estimate than would be obtained from using the bank data only. As more refined information on specific countries is obtained, it is envisaged that this series will be updated. 
Table A1: Relating survey-based access percentages and information on account numbers

\begin{tabular}{|c|c|c|c|c|c|c|c|c|c|c|c|c|}
\hline \multirow{3}{*}{$\begin{array}{l}\text { Equation: } \\
\text { Dep. var. } \\
\text { Explanatory var. }\end{array}$} & \multirow{3}{*}{$\begin{array}{r}\text { A1.A } \\
\text { survsave } \\
\text { Coeff. }\end{array}$} & \multirow{2}{*}{\multicolumn{2}{|c|}{$\begin{array}{r}\text { A1.B } \\
\text { survsave }\end{array}$}} & \multirow{2}{*}{\multicolumn{2}{|c|}{$\begin{array}{r}\text { A1.C } \\
\text { survsave }\end{array}$}} & \multirow{2}{*}{\multicolumn{2}{|c|}{$\begin{array}{r}\text { A1.D } \\
\text { survsave }\end{array}$}} & \multirow{2}{*}{\multicolumn{2}{|c|}{$\begin{array}{r}\text { A1.E } \\
\text { survsave }\end{array}$}} & \multirow{2}{*}{\multicolumn{3}{|c|}{$\begin{array}{r}\text { A1.F } \\
\text { survsave }\end{array}$}} \\
\hline & & & & & & & & & & & & \\
\hline & & t-Stat & Coeff. & $\mathrm{t}$-Stat & Coeff. & $\mathrm{t}$-Stat & Coeff. & $\mathrm{t}$-Stat & Coeff. & $\mathrm{t}$-Stat & Coeff. & t-Stat \\
\hline Constant & -115.0 & $* * 5.6$ & 186.1 & $\star * 9.5$ & -63.0 & 1.0 & -60.5 & 0.9 & 14.6 & $* * 3.2$ & 8.17 & 1.7 \\
\hline Log (Bank accs per pop) & 25.2 & $\star * 8.1$ & 18.8 & $\star * 8.0$ & 11.8 & $\star * 2.9$ & 11.5 & 2.1 & & & 0.0190 & $\star * 4.9$ \\
\hline Log (Average deposit size) & & & 14.0 & $\star \star 4.9$ & 2.4 & 0.4 & 2.2 & 0.3 & & & 0.00362 & $* * 3.5$ \\
\hline Alternative accs per pop & & & & & & & 0.017 & 0.0 & 0.701 & $* * 3.1$ & & \\
\hline Omitted observation & & & & & Adv & & Adv & & Adv & & & \\
\hline R-squared / NOBS & 0.814 & 17 & 0.931 & 17 & 0.601 & 10 & 0.601 & 10 & 0.315 & 23 & 0.895 & 17 \\
\hline Adjusted R-squared & 0.801 & & 0.921 & & 0.486 & & 0.401 & & 0.282 & & 0.880 & \\
\hline S.E. of regression & 15.8 & & 10.0 & & 9.5 & & 10.2 & & 14.1 & & 12.3 & \\
\hline Log likelihood & -70.0 & & -61.5 & & -34.9 & & -34.9 & & -92.5 & & -65.1 & \\
\hline
\end{tabular}


Table A1 (continued)

\begin{tabular}{|c|c|c|c|c|c|c|c|c|c|c|c|c|}
\hline \multirow{2}{*}{$\begin{array}{l}\text { Equation: } \\
\text { Dep. var. } \\
\text { Explanatory var. }\end{array}$} & \multicolumn{2}{|c|}{$\begin{array}{l}\text { A1.G } \\
\text { survsave }\end{array}$} & \multicolumn{2}{|c|}{$\begin{array}{l}\text { A1.H } \\
\text { survsave }\end{array}$} & \multicolumn{2}{|c|}{$\begin{array}{l}\text { A1.J } \\
\text { survsave }\end{array}$} & \multicolumn{2}{|c|}{$\begin{array}{l}\text { A1.K } \\
\text { survsave }\end{array}$} & \multicolumn{2}{|c|}{$\begin{array}{l}\text { A1.L } \\
\text { Depaccs }\end{array}$} & \multicolumn{2}{|c|}{$\begin{array}{l}\text { A1.M } \\
\text { Depsize }\end{array}$} \\
\hline & Coeff. & t-Stat & Coeff. & t-Stat & Coeff. & t-Stat & Coeff. & t-Stat & Coeff. & t-Stat & Coeff. & t-Stat \\
\hline Constant & -115.9 & **6.9 & -121.9 & $* \star 8.3$ & -188.2 & $* * 9.5$ & -151.0 & 2.0 & 156.7 & $\star 2.5$ & 1356 & $\star 2.8$ \\
\hline Log (Bank accs per pop-synthetic) & 25.2 & $\star \star 9.5$ & 26.4 & $\star \star 11.2$ & 18.2 & $\star * 7.3$ & 15.4 & *2.5 & & & & \\
\hline Log (Avg deposit size-synthetic) & & & & & 14.8 & $* \star 4.7$ & 11.7 & 1.6 & & & & \\
\hline Alternative accs per pop & & & & & & & 0.131 & 0.4 & 12.9 & $\star \star 5.9$ & & \\
\hline GDP per cap & & & & & & & & & & & 0.280 & $\star * 9.4$ \\
\hline Omitted observation & & & ROM & & & & & & ROM & & & \\
\hline R-squared / NOBS & 0.761 & 30 & 0.823 & 29 & 0.869 & 30 & 0.485 & 23 & 0.762 & 13 & 0.822 & 21 \\
\hline Adjusted R-squared & 0.753 & & 0.817 & & 0.859 & & 0.403 & & 0.740 & & 0.813 & \\
\hline S.E. of regression & 15.2 & & 13.2 & & 11.5 & & 12.9 & & 178.3 & & 1735 & \\
\hline Log likelihood & -123.2 & & -115.0 & & -114.2 & & -89.2 & & -84.7 & & -185.4 & \\
\hline
\end{tabular}

Note: Regressions A-F in this table relate survey-based estimates of the percentage of households who have bank accounts (Survsave) to estimates of the number of bank accounts per head of population, average bank deposit size, and the number of accounts at 'alternative' financial intermediaries per head of population. Regressions G-K repeat this substituting fitted values for the first two explanatory variables from Regressions $L$ and $M$. Regression $L$ relates the number of bank accounts per head of population to the number of accounts at 'alternative' financial intermediaries. Regression M relates average bank deposit size to GDP per capita. ** and * indicate significance at the $1 \%$ and $5 \%$ levels, respectively. NB: regression $1 \mathrm{~F}$ uses the levels rather than the logs of $\{$ Bank accs per pop\} and $\{$ Avg deposit size\}. Omitted observations: regressions C-E omit advanced economies. ${ }^{*}$ and * indicate significance at the $1 \%$ and $5 \%$ levels, respectively. The synthetic explanatory variables are the fitted values from equations $1 \mathrm{~L}$ and $1 \mathrm{M}$. Omitted observations: regressions $\mathrm{H}$ and $\mathrm{L}$ omit the outlier Romania.

Source: Author's regression estimates 


\section{References}

Aghion, P., P. Howitt, and D. Mayer-Foulkes (2005). 'The Effect of Financial Development on Convergence: Theory and Evidence', Quarterly Journal of Economics 120(1): 173-222

Aizcorbe, A.M., A.B. Kennickell, and K.B. Moore (2003). 'Recent Changes in US Family Finances: Evidence from the 1998 and 2001 Survey of Consumer Finances.' Federal Reserve Bulletin 481

Ameriks, J., and S.P. Zeldes (2004). 'How Do Household Portfolio Shares Vary with Age?', www1.gsb.columbia.edu/mygsb/faculty/research/pubfiles/16/Ameriks\#Zeldes _age_Sept_2004d.pdf

Armendáriz de Aghion, B., and J. Morduch (2005). The Economics of Microfinance, MIT Press: Cambridge MA.

Beck, T., A. Demirguc-Kunt, and R. Levine (2004). 'Finance, Inequality and Poverty: Cross Country Evidence', World Bank Policy Research Working Paper 3338, World Bank: Washington DC.

Beck, T., M.S. Martinez Peria, and A. Demirguc-Kunt (2005). 'Reaching Out: Access to and Use of Banking Services across Countries', World Bank Policy Research Working Paper 3754, World Bank: Washington DC.

Bergstresser, D., and J. Poterba (2004). 'Asset Allocation and Asset Location: Household Evidence from the survey of Consumer Finances', Journal of Public Economics 88: 1893-915.

Boutchkova, M.K., and W.L. Megginson (2000). 'Privatization and the Rise Of Global Capital Markets’, Financial Management 29: 31-76.

Bucks, B.K., A.B. Kennickell, and K.B. Moore (2006). 'Recent Changes in U.S. Family Finances: Evidence from the 2001 and 2004 Survey of Consumer Finances.' Federal Reserve Bulletin 92: A1-A38.

Campbell, J.Y. (2006). 'Household Finance.' Journal of Finance, forthcoming, http://kuznets.fas.harvard.edu/ campbell/papers/AFApresidentialaddress032106.pdf

Carbó, S., E.P.M. Gardener, and P. Molyneux (2005). Financial Exclusion, Palgrave Macmillan: Basingstoke.

Carroll, C.D. (2002). 'Portfolios of the Rich', in Guiso et al.

Christen, R.P, V. Jayadeva, and R. Rosenberg (2004). 'Financial Institutions with a Double Bottom Line: Implications for the Future of Microfinance', CGAP Occasional Paper 8, CGAP: Washington DC. 
Claessens, S. (2005). 'Access to Financial Services: A Review of the Issues and Public Policy Objectives’, World Bank Policy Research Working Paper 3789, World Bank: Washington DC.

Davies, J., S. Sandström, A.F. Shorrocks, and E.N. Wolf (2006). 'Estimating the World Distribution of Household Wealth', paper prepared for UNU-WIDER project meeting, 4-6 May, WIDER: Helsinki.

Dehejia, R.H., and R. Gatti. (2005). 'Child Labour: The Role of Income Variability and Access to Credit in a Cross Section of Countries', Economic Development and Cultural Change 53(4): 913-32.

Djankov, S., C. McLiesh, and A. Shleifer (2006). 'Private Credit in 129 Countries', Journal of Financial Economics, forthcoming, http://www.doingbusiness.org/ documents/private_credit_jan23.pdf

Ellerman, D. (2001). 'Lessons from Eastern Europe's Voucher Privatization', Challenge 44(4): $14-37$.

European Commission (2005). 'Public Opinion in Europe on Financial Services', Special Eurobarometer 230, http://europa.eu.int/comm/consumers/cons_int/ fina_serv/cons_experiences/background_en.htm

Giannetti, M. and Y. Koskinen (2004). 'Investor Protection and the Demand for Equity’, CEPR Working Paper 4017, Centre for Economic Policy Research: London.

Goetzmann, W.N., and A. Kumar (2004). 'Why Do Individual Investors Hold Underdiversified Portfolios?', mimeo, Yale University and University of Notre Dame, http://ssrn.com/abstract=627321.

Guiso, L., M. Haliassos, and T. Jappelli (2002). Household Portfolios, MIT Press: Cambridge MA.

Guiso, L., M. Haliassos, and T. Jappelli (2003). 'Household Stockholding in Europe: Where Do We Stand and Where Do We Go?’, Economic Policy 36: 123-70.

Guiso, L., P. Sapienza, and L. Zingales (2005). 'Trusting the Stock Market', http://gsbwww.uchicago.edu/fac/luigi.zingales/research/PSpapers/trusting_stock.pdf.

Hanson, J.A. (2003). ‘Are Small Countries Underbanked?’, in J.A. Hanson, P. Honohan, and G. Majnoni (eds) Globalization and National Financial Systems, Oxford University Press: New York.

Honohan, P. (2004a). 'Financial Development, Growth and Poverty: How Close Are the Links?', in C. Goodhart (ed.) Financial Development and Economic Growth: Explaining the Links, Palgrave: London.

Honohan, P. (2004b). 'Financial Sector Policy and the Poor: Selected Issues and Evidence', World Bank Working Paper 43, World Bank: Washington DC. 
Honohan, P. (2005). 'Measuring Microfinance Access: Building on Existing CrossCountry Data’, World Bank Policy Research Working Paper WPS 3606.

Huizinga, H. and L. Jonung (2005). The Internalization of Asset Ownership in Europe, Cambridge Univerity Press: Cambridge.

Iwaisako, T. (2003). 'Household Portfolios in Japan'. NBER Working Paper 9647, National Bureau of Economic Research: Cambridge MA.

Jäntti, M. and E. Sierminska (2006), 'Wealth Distribution in OECD Countries', paper prepared for UNU-WIDER project meeting, 4-6 May, WIDER: Helsinki.

Johnson, S., J. McMillan, and C. Woodruff (2002). 'Property Rights and Finance', American Economic Review 92(5): 1335-56.

Kar, Pratip, M.T. Raju, and S.P. Batra. (2003). 'Survey of Indian Investors', Securities and Exchange Board of India: Mumbai.

Kelly, M. (1995). 'All their Eggs in One Basket: Portfolio Diversification of US Households', Journal of Economic Behavior and Organization 27(1): 87-96.

Kennickell, A.B. (2003). 'A Rolling Tide: Changes in the Distribution of Wealth in the U.S., 1989-2001’, Levy Economics Institute of Bard College Working Paper 393.

King, M.A., and J.I. Leape (1998). 'Wealth and Portfolio Composition: Theory and Evidence', Journal of Public Economics 69: 155-93.

Levine, R.E. (2005). 'Finance and Growth: Theory, Mechanisms and Evidence', in P. Aghion, and S.N. Durlauf (eds). Handbook of Economic Growth, Elsevier: Amsterdam.

Li, H., L. Squire, and H. Zou (1998). 'Explaining International and Intertemporal Varriations in Income Inequality’, Economic Journal 108(1): 26-43.

Li, S., and Z. Renwei (2006). 'The Changes in the Distribution of Wealth in China, 1995-2002, paper prepared for UNU-WIDER project meeting, 4-6 May, WIDER: Helsinki.

Lusardi, A., and O. Mitchell (2006). 'Financial Literacy and Planning: Implications for Retirement Wellbeing', presented at American Economic Association, 6-8 January, Boston.

NSSO (National Social Survey Organization) (2005). 'Household Assets and Liabilities in India’, NSSO: Delhi, http://mospi.nic.in/mospi_nsso_rept_pubn.htm

Oijen, P. van, and EC. Perotti (2001). 'Privatization, Market Development and Political Risk in Emerging Economies', Journal of International Money and Finance 20(1): 43-69. 
Peachey, S., and A. Roe (2006). 'Access to Finance, Measuring the Contribution of Savings Banks', World Savings Banks Institute: Brussels, http://www.dartmouth.edu/ alusardi/Lusardi_Mitchell_march06.pdf

Porteous, D., with E. Hazelhurst (2004). Banking on Change: Democratizing Finance in South Africa 1994-2004 and Beyond, Double Storey Books: Cape Town.

Rajan, R.G., and L. Zingales (2003). Saving Capitalism from the Capitalists, Crown Business: New York.

Rioja, F., and N. Valev (2004). 'Finance and the Sources of Growth at Various Stages of Economic Development', Economic Inquiry 42(1): 127-40.

Robinson, M.S. (2001). The Microfinance Revolution: Sustainable Finance for the Poor, World Bank: Washington DC.

Rosen, H.S., and S. Wu (2004). 'Portfolio Choice and Health Status', Journal of Financial Economics 72(3): 457-84.

Subramanian, S., and D. Jayaraj (2006). 'The Distribution of Household Wealth in India', paper prepared for UNU-WIDER project meeting, 4-6 May, WIDER: Helsinki.

Waldenström, D., and J. Vlachos (2005). 'International Financial Liberalization and Industry Growth', International Journal of Finance \& Economics 10(3): 263-84.

World Bank (2005). 'Measuring Financial Access: Outlining the Scope of Current Data Collection Efforts', World Bank: Washington DC. http://siteresources.worldbank.org/FINANCIALSECTOR/214574-1097771341979/ 20649884/Measuring_Fin_Access.pdf.

Yoo, K. (2005). 'Empirical Analysis of Portfolio Allocation: The Case of Korea', mimeo, Bank of Korea: Seoul. 